\title{
SIMULACIÓN Y SUBTERFUGIO LABORAL: A PROPÓSITO DEL ALCANCE DEL ACTUAL ARTÍCULO 507 DEL CODIGO DEL TRABAJO CHILENO*
}

\author{
SIMULATION AND LABOR SUBTERFUGE: \\ REGARDING THE SCOPE OF CURRENT ARTICLE 507 \\ OF THE CHILEAN LABOR CODE \\ SIMULATION ET SUBTERFUGES UTILISÉS DANS LE MONDE \\ DU TRAVAIL: LE CHAMP D'APPLICATION DE L'ACTUEL \\ ARTICLE 507 DANS LE CODE DU TRAVAIL CHILIEN
}

Francisco Alberto RUAY SÁEZ**

\begin{abstract}
RESUMEN: En la presente exposición se pretende explorar cuáles son los alcances de las figuras de "simulación" y "subterfugio laboral", contenidos y tipificados en el artículo 507 del Código del Trabajo actualmente vigente en Chile, introducidos a través de la reforma legal denominada "Ley Multirut". Se realiza una exposición sobre las discusiones doctrinarias desarrolladas a propósito del antiguo artículo 478 del Código del Trabajo chileno, su relación con instituciones conexas como lo son el fraude a la ley o el levantamiento del velo corporativo, para luego afrontar críticamente la lectura del actual texto legal vigente en el artículo 507 y su vinculación con la declaración de único empleador.
\end{abstract}

Palabras clave: simulación laboral, subterfugio laboral, Ley Multirut, ius puniendi.

ABSTRACT: This presentation attempts to explore the scopes of the concept of "simulation" and "labor subterfuge" contained and defined in article 507 of the Labor Code currently in force in Chile, which has been

\footnotetext{
* Recibido el 9 de enero de 2017 y aceptado para su publicación el 4 de septiembre de 2017.

** Estudiante de Magíster en Derecho del Trabajo y de la Seguridad Social, Universidad de Chile. Ayudante ad honorem de los departamentos de Derecho del Trabajo y de la Seguridad Social, y de Ciencias Penales en la Facultad de Derecho de la Universidad de Chile. Correo electrónico: fruay@ug.uchile.cl; fruaysaez@gmail.com; francisco.ruay@ppulegal.com.
} 
introduced by means of the legal reform denominated "Multirut Law". The doctrine discussions developed regarding article 478 of the Chilean Labor Code, its link to the related concepts such as fraud to the law and the lifting of the corporate veil, to later critically face the reading of the currently text in force found in article 507 and its connection to the statement of sole employer are presented.

Keywords: labor simulation, labor subterfuge, Multirut Law, ius puniedi.

RÉSUMÉ: L'objectif du présent travail consiste à analyser les champs d'application exploitables pour les différents cas de "simulation" et de "subterfuges" dans le monde du travail tels qu'ils sont mentionnés et définis par l'article 507 du Code du Travail actuellement en vigueur au Chili que la réforme juridique dénommée "Loi Multirut" a rendu possible. Les différents débats qui ont vu le jour et portant sur la doctrine juridique relative à l'ancien article 478 du Code du Travail chilien sont ainsi passés en revue ainsi que leurs liens avec les thèmes connexes comme l'escroquerie vis-à-vis de la loi ou le fait d'obliger une entreprise à dévoiler ses pratiques fiscales afin d'aborder, ensuite, avec un œil critique, le texte juridique actuel en vigueur dans l'article 507 et ses rapports avec la déclaration d'employeur unique.

Mots-clés : simulation et subterfuges dans le monde du travail, Loi Multirut, ius puniendi.

SUMARIO: I. Introducción. II. El problema de la determinación del empleador en el derecho comparado. III. El intento legislativo de otorgar una solución. IV. Sobre el artículo 507 del Código del Trabajo chileno actualmente vigente. V. Simulación y subterfugio: algunos conflictos hermenéuticos posibles. VI. Hacia una determinación de los conceptos de simulación y subterfugio en el actual artículo 507 del Código del Trabajo. VII. Alcances de la nueva forma de regulación del articulo 507 en torno a las figuras de subterfugio y simulación. VIII. La sanción contemplada en la ley como ejercicio del ius puniendi estatal a través del Estado juez. IX. A modo de conclusión. X. Bibliografía.

\section{INTRODUCCIÓN}

$\mathrm{H}$ istóricamente, por la posición jurídica y material desmejorada ${ }^{1}$ en que se han encontrado los trabajadores desde la industrialización de la

\footnotetext{
1 "El derecho del trabajo aparece así como una respuesta jurídica y normativa —origina-
} 
producción, los trabajadores se han unido colectivamente para hacer una única fuerza, no solamente en busca de la protección y garantía institucional de derechos laborales tradicionales o específicos, sino que ha terminado por ampliar su búsqueda hacia la consagración y reconocimiento de los denominados derechos inespecíficos, ${ }^{2}$ persiguiendo su eficacia jurídica y la consecuente ampliación del ámbito cautelar de los mismos. Pero, aún antes que aquello, ha sido objeto de batalla constante la búsqueda de los trabajadores por ser reconocidos formalmente en su calidad de tales, como subordinados y dependientes, ${ }^{3}$ por quienes usufructúan de la fuerza de trabajo con causa de la contratación laboral. Búsqueda de reconocimiento que no sólo se sa-

riamente de fuente estatal y luego también producto de la autonomía colectiva- que reconoce tanto la falta de libertad de quien es contratado — carencia que es a su vez consecuencia de su necesidad económica - como la resignación de libertad que supone la sumisión a los poderes jerárquicos del empleador. Y a partir de tales reconocimientos, despliega una serie de reglas y diseña un conjunto de medios técnicos para poner límites tanto a las consecuencias de la posición de supremacía del empleador como a la resignación de libertad por el trabajador". Ackerman, Mario E., "Contrato de servicios y contrato de trabajo. La protección de la persona en las fronteras del derecho del trabajo", Revista Latinoamericana de Derecho, año IV, núm. 7-8, enero-diciembre de 2007, pp. 1-24.

$2 \mathrm{Al}$ respecto el profesor Ugarte ha señalado que “[e]l Derecho del Trabajo ha cumplido y cumple así diversas funciones, de modo simultáneo, preocupado de la protección de los derechos de los trabajadores en diversos planos: 1. Los derechos laborales propiamente tales (salarios mínimos, jornada de trabajo, indemnizaciones por término de contrato), atribuidos al trabajador como contratante débil, que ha permitido asegurar un mínimo socialmente aceptable para los trabajadores, 2. Los derechos fundamentales específicos (libertad sindical, derecho negociación colectiva, huelga) atribuidos al trabajador como miembro de una organización de representación de intereses, que han permitido al Derecho del Trabajo intentar democratizar la dirección económica y política de las empresas y de algún modo de la propia sociedad, y por último 3. Los derechos fundamentales inespecíficos (intimidad, integridad, libertad de expresión, no discriminación), atribuidos al trabajador en su calidad de ciudadano, han permitido al Derecho del Trabajo garantizar al interior de las empresas un trato digno y acorde con un miembro de una sociedad democrática". Ugarte Cataldo, José Luis, "La tutela de derechos fundamentales y el derecho del trabajo: de erizo a zorro", Revista de Derecho, Universidad Austral de Chile, Valdivia, vol. XX, núm. 2, diciembre de 2007, pp. 51-52. En el mismo sentido Gamonal en: Gamonal Contreras, Sergio. Ciudadanía en la empresa o los derechos fundamentales inespecificos, FCU, Montevideo, Uruguay, 2004, pp. 13 y ss.

3 El origen del derecho del trabajo sería "propiamente la reacción ante el conflicto entre el capital y el trabajo asalariado en la sociedad capitalista industrial, esto es, el conflicto que se genera en la gran industria" del siglo XIX caracterizada por la doble concentración de capitales y de trabajadores. Caamaño Rojo, E., "El empleo en las fronteras del derecho del trabajo. El trabajo autónomo económicamente dependiente", Revista Laboral Chilena, núm. 132, diciembre 2004, parte I, pp. 61-71. 
tisface como instancia retórica romántica en la que pareciese obtenerse un ideal socialmente relevante sino, ante todo, porque es precisamente a través del reconocimiento de los trabajadores, en su calidad de tales, que el ordenamiento jurídico entenderá que quedan dichos sujetos de derecho bajo al alero proteccionista que el Estado ofrece a través del derecho del trabajo.

La búsqueda por el reconocimiento de la posición de sujeto jurídico en el contexto de la relación laboral tiene, en primer lugar, el objetivo de mostrar que el sujeto en cuestión está legitimado para invocar la cobertura jurídica estatal que otorga el estatuto respectivo, pero inmediatamente, también, quiere develar ante los órganos jurídicos competentes quién es el sujeto pasivo de las obligaciones laborales libremente contraídas entre las partes, ${ }^{4}$ y titular por tanto de la gama de derechos subjetivos que el estatuto jurídico mínimo consagra en la positivización e institucionalización del ordenamiento laboral vigente. En principio, desde la propia consagración normativa, la declaración formal de una relación laboral pretende atacar el fraude laboral, ${ }^{5}$ en cuanto continuamente podemos verificar situaciones en que se contratan (consensualmente) la prestación de servicios pretendiendo aún mantenerse al margen del estatuto laboral proteccionista que el Estado de derecho ofrece.

El trabajador, como sujeto imbuido en una posición subjetiva concreta, clama por el reconocimiento jurídico de su calidad de tal, pero a la vez, dicha circunstancia supone la correcta determinación correlativa de los sujetos ante quienes podrá exigir los derechos que se han consagrado como mínimos en la legislación laboral ${ }^{6}$, y aquellos que tanto en la práctica efectiva, como a través

\footnotetext{
4 “¿Hasta qué punto la manifestación de voluntad por parte de los trabajadores es válida? El juzgador deberá cuidar con suma prudencia la aplicación del orden público, solamente podrá anular aquello que resulte en una burda violación de la ley. No puede dejar de asignarle valor a una manifestación de voluntad por parte del trabajador, argumentando las limitaciones que establece el orden público, de lo contrario, ocurriría sostener que "el obrero es un ser absolutamente incapaz para comprometer su voluntad, lo que resulta lesivo de su dignidad humana". El derecho del trabajo se propone proteger la personalidad humana; resulta imposible suprimir la libre manifestación de una de las supremas cualidades de esa personalidad: su voluntad". Lastra, José Manuel, "Paradojas de la autonomía de la voluntad en las relaciones de trabajo", Revista de Derecho Privado, nueva serie, nueva época, año II, núm. 5, mayo-agosto, 2003, pp. 133-134.

5 Goldín, Adrián, "El fraude laboral y los contratos afines", Buenos Aires, La Ley, año LXXV, núm. 181, 22 de septiembre de 2011, pp. 1-8.

6 La autoridad administrativa ha señalado sistemáticamente que los tribunales no tienen facultades para la calificación de relaciones jurídicas como aquellas de naturaleza laboral, y así
} 
de actos documentales formales suscritos entre las partes de la relación jurídica en cuestión han consentido libremente. En ese sentido resulta relevante la noción de "créditos laborales", pues originariamente es para su protección que se ha configurado el derecho del trabajo (individual, al menos). En ese sentido se ha señalado que "los créditos laborales son derechos personales que sólo son exigibles a una determinada persona que ha contraído la obligación correlativa; así los créditos laborales son exigibles al empleador, es esta una persona natural o una empresa. De allí la importancia de su identificación precisa". 7

Por lo mismo, resulta relevante la determinación precisa del sujeto de derecho "empleador"; sujeto pasivo de las obligaciones positivizadas en el estatuto laboral respectivo, y en las contractuales que las partes pudieron legítimamente contraer. Los trabajadores requieren tener certeza de cuál será el patrimonio que responderá de sus legítimas pretensiones, de lo contrario, el propio derecho del trabajo y su regulación normativa imperativa abandonan el espíritu con que se constituyeron e institucionalizaron originalmente, y conceptualizaciones como la de "orden público laboral" pierden todo sentido y eficacia normativa y práctica. Más aún en un contexto de descentralización productiva en que "la empresa rompe su esquema tradicional de organización productiva, en torno al cual se construye el ordenamiento jurídico laboral clásico, y se fragmenta en una serie de entidades independientes entre sí desde un punto de vista jurídico, dando lugar a la formación de verdaderas redes", 8 la práctica jurídica laboralista clama por una preocupación especial ante fenómenos contemporáneos como el de la denominada "parasubordinación", ? propios de esta nueva etapa del capitalismo. ${ }^{10}$

\footnotetext{
lo han abordado críticamente los doctrinarios ius laboralistas, véase Caamaño Rojo, Eduardo, "Análisis crítico sobre la aplicación de la doctrina de los actos propios en materia laboral", Revista de derecho, Valparaíso, núm. 32, 2009, pp. 261-280; Rojas Miño, Irene, "La externalización laboral y la cesión ilegal de trabajadores en el sistema jurídico chileno", Revista Ius et Praxis, vol. 16, núm. 1, 2010, pp. 171-196.

7 Vergara del Río, Mónica, "El concepto laboral de empresa y los créditos laborales", Revista Laboral Chilena, año 13, núm. 12, 2003.

8 Caamaño Rojo, E., "El empleo en las fronteras del derecho del trabajo...", cit., p. 69.

9 Caamaño Rojo, E., "El empleo en las fronteras del derecho del trabajo. El trabajo autónomo económicamente dependiente", Revista Laboral Chilena, núm. 133, enero 2015, parte II, p. 68.

10 Giner, Salvador, El futuro del capitalismo, Argentina, Editorial Península, 2010, p. 45.
} 
Sin embargo, en el ordenamiento jurídico nacional chileno es preciso también vislumbrar y reconocer los legítimos intereses particulares que libremente han decidido confluir para la configuración de entidades jurídicas colectivas diversas a las de su propia personalidad y patrimonio individual. En dicho sentido, resulta evidente que no toda persona jurídica constituida esconde tras de sí una intencionalidad maliciosa o perniciosa, particularmente perjudicial en materia laboral (de hecho puede ser resultado de una programación financiera, territorial administrativa, de gestión comercial, u otra cualquiera). ${ }^{11}$ Resulta además relevante ser conscientes de que un uso indebido de las herramientas dogmáticas por la autoridad laboral, judicial o administrativa, puede implicar "la negación al empleador de su libertad de contratación laboral, reconocida explícitamente en el artículo 19, núm. 16, CPR. El contenido de esta garantía fue definido con sencillez y claridad paradigmáticas en el seno de la Comisión de Estudios para la Nueva Constitución, donde se dijo que "en su esencia este derecho asegura que a nadie le será impuesto un trabajo o un trabajador". Se trata, pues, de una libertad bifronte, con una cara que mira hacia el trabajador y otra al empleador". ${ }^{2}$ Así, una extralimitación potestativa significaría la imposición de trabajadores, que ha de quedar proscrita, tal como el caso de la imposición de trabajo forzoso.

Conforme a lo señalado, las situaciones que requerirían una salvaguarda jurídica en materia laboral son aquellas que podríamos denominar "patológicas". En ese sentido, "La patología se pone de manifiesto cuando el empleador material interpone entre él y sus trabajadores a un tercero como empleador aparente o testaferro, con el fin de ocultar su persona o patrimonio o bien cuando realiza alteraciones maniobras que traen como consecuencia un perjuicio o menoscabo para sus trabajadores". ${ }^{13}$

11 "Las reestructuraciones societarias buscan fines muy distintos al fraude laboral. En efecto, los procesos de división, filialización u otras formas de dispersión societarios obedecen casi siempre a optimizaciones operativas y/o tributarias de las empresas y, en general, a motivos totalmente legítimos y ajenos a lo laboral". Palavecino Cáceres, Claudio, "De la empresa como pura facticidad a la relación de trabajo sin contrato", Revista Chilena de Derecho del Trabajo y de la Seguridad Social, vol. 2, núm. 4, 2011, p. 26.

12 Palavecino Cáceres, Claudio, "De la empresa como pura facticidad...”, cit., p. 21.

13 Palavecino Cáceres, Claudio, "El tipo subjetivo en la simulación y subterfugio en perjuicio de los trabajadores", El Mercurio Legal, 1 de abril de 2013, disponible en: http:/ / wmw. elmercurio.com/Legal/Noticias/Opinion/2013/04/01/El-tipo-subjetivo-en-la-simulacion-y-subterfugio-enperjuicio-de-los-trabajadores.aspx, consultado el 28 de noviembre de 2016. 
El tema que aborda la presente investigación, por tanto, se relaciona con una de las pretensiones fundamentales de los trabajadores, que versa con su reconocimiento por su calidad de tales. Globalmente se ha reconocido que la formalidad o escrituración de documentos no limita ni restringe de ninguna manera la determinabilidad de las relaciones jurídicas laborales. La actuación intencionada de eludir la sujeción a la normativa laboral, ha sido relatada como una forma de simulación o una forma de subterfugio laboral (términos de origen civilista). Ahora bien, ¿es posible separar la determinación de una relación jurídica de trabajo de la constatación de un subterfugio o simulación? Si entendemos que estos últimos requerirán la presencia de un elemento subjetivo por parte del actor (empleador encubierto), estaremos frente a la posibilidad de que se pueda declarar la existencia (constatar y declarar) de una relación laboral, sin que aquello implique necesariamente, y de manera ineludible, la declaración de subterfugio o simulación laboral.

La dinámica en que funcionan por cercanía los conceptos de fraude laboral, simulación, subterfugio, cesión ilegal de trabajadores, entre otras, se torna relevante en cada uno de los sistemas jurídicos, y precisamente es necesario diseñar elementos doctrinarios que pretendan afrontar su determinación. En ese sentido, la presente investigación pretende representar un aporte en esa dirección.

En este artículo no nos referiremos de manera específica y ampliada a las figuras sancionatorias de los casos patológicos de externalización impropia de labores, esto es, subcontratación ilícita, sin cobertura legal, o de suministro ilícito de trabajadores, ${ }^{14}$ que pudiesen por sí mismos encerrar una figura sancionatoria especial para los casos en que se estime que se ha incurrido en un supuesto "fraude a la ley", ${ }^{15}$ ni menos abordaremos una crítica de fondo

14 Lizama Portal, Luis y Ugarte Cataldo, José Luis, Subcontratación y suministro de trabajadores, 4a. ed., Santiago de Chile, Legal Publishing, 2009, pp. 114 y ss.

15 A propósito de la regulación de estas figuras ha señalado Ugarte que "la ley cierra el andamiaje normativo descrito [sobre suministro de trabajadores] con un sistema de sanciones en contra de la empresa usuaria en casos de infracción y de fraude a la ley: En el primer caso, la usuaria responde por infracción a la ley laboral cuando contrate a un trabajador de servicios temporarios por intermedio de empresas no inscritas en el registro que para tales efectos llevará la Dirección del Trabajo. La sanción será, aparte de la multa que corresponda, que el trabajador respectivo se considerará como dependiente de la usuaria, vínculo que se regirá por las normas de la legislación laboral común (artículo 183 AA). En el segundo caso, la usuaria responde por fraude a la ley laboral cuando ha celebrado con- 
sobre la posibilidad de concebir a la subcontratación como una relación laboral encubierta, por definición. ${ }^{16}$ El objetivo planteado, tal como se desprende del título, es el análisis de las figuras de simulación y subterfugio en la relación de trabajo, sirviendo de manera ejemplar la modelación legislativa que se encuentra vigente en Chile. Señalemos al respecto, en todo caso, que para el caso de las empresas de servicios transitorios, y en relación a la puesta a disposición ilegal de trabajadores, se ha establecido una sanción propia cual es atribución de la calidad de empleador de la usuaria. Mientras que en el caso de la subcontratación se han establecido una serie de prerrogativas que abogan por desincentivar la subcontratación, o al menos, incentivar la vigilia y cautela de la empresa principal respecto del cumplimiento de obligaciones laborales y previsionales de la contratista, estableciendo una especial "solidaridad" para

tratos de trabajo en supuestos distintos a aquellos que justifican la contratación de servicios temporarios, o que tengan por objeto encubrir una relación de trabajo de carácter permanente con la usuaria, se entenderán celebrados en fraude a la ley, considerándose el trabajador como dependiente de la usuaria, vínculo que se regirá por las normas de la legislación laboral común, sin perjuicio de las demás sanciones que correspondan (artículo 183 U)”. Ugarte Cataldo, José Luis, "Sobre relaciones laborales triangulares: La subcontratación y el suministro de trabajadores", Revista Ius et Praxis, Talca, vol. 12, núm. 1, 2006, pp. 11-29.

16 Para una lectura crítica del fenómeno de descentralización productiva, por ejemplo, Nava y Hernández señalan que: “en las sociedades modernas regidas por la globalización las empresas están desechando los contratos fijos de trabajo acudiendo a la subcontratación tanto del trabajador como de empresas para prestar servicios, asunto que establece una de las peores alternativas en el mundo del trabajo, ya que está destinada a ocultar la relación de trabajo bajo una figura mercantil, con la cual se excluyen los derechos de los trabajadores, incurriendo en lo que se ha denominado relaciones laborales encubiertas o fraude laboral.

La subcontratación como forma de contrato se perfila hacia el abaratamiento de los costos laborales, favoreciendo la precarización del empleo, la desregulación de la relación laboral, incluida la determinación de las responsabilidades.

Surgen por tanto formas de trabajo atípicas propiciadas por el empresario y aceptadas por el trabajador ante el dilema de quedar excluido del mercado de trabajo. Este dilema se convierte en una irracional fundamentación para que la protección legal del trabajador cese, dando paso a relaciones encubiertas.

El auge de esta práctica produce efectos nocivos para el trabajador, entre los cuales se presentan: la dificultad del acceso a los derechos sociales de manera continuada, debido a que vive entre la exclusión del mercado de trabajo y el subcontrato. Por otra parte, se modifica la naturaleza del mercado de trabajo al presionar hacia la precarización de los salarios, ultrajando las relaciones laborales al convertir al trabajador en un supuesto "trabajador autónomo" que no goza de la plusvalía generada". Nava, Yuneska y Hernández, Carmen Añez, "Subcontratación: relación laboral encubierta", Telos, Revista de estudios interdisciplinarios de Ciencias Sociales, septiembre-diciembre de 2012, pp. 333-345. 
casos en que no se logre acreditar la diligencia informativa y de retención, conforme se regula en los artículos 183-A y siguientes del Código del Trabajo.

\section{EL PROBLEMA DE LA DETERMINACIÓN DEL EMPLEADOR \\ EN EL DERECHO COMPARADO}

Antes de entrar directamente en el análisis del caso chileno, hemos de contextualizar la relevancia global del tema de la determinación clara de las partes de la relación laboral y, en particular, de la determinación del empleador como sujeto pasivo de las obligaciones laborales y previsionales del trabajador. Es precisamente en ese ocultamiento de la condición de empleador en donde entran en juego las nociones de "simulación", "fraude", "subterfugio" y "abuso del derecho". Dichas figuras serían las utilizadas por los empleadores de las diversas partes del mundo para esconder su calidad de tales, y es sobre este tema sobre el que versará nuestro trabajo.

Hay sectores productivos en donde la problemática de la formalidad laboral se conecta directamente con las nociones fraude laboral y precarización, y la determinación de la condición de empleador resulta un factor de análisis histórico de suma relevancia. ${ }^{17}$ Pero además, la preocupación por la necesaria formalización de la relación laboral, y la persecución de situaciones de encubrimientos ilícitos de la misma, ha sido un asunto de preocupación doctrinaria y legal a nivel global.

Para la OIT, la determinación y correcta calificación de la relación laboral, y de manera consiguiente, de la calidad de empleador de una de sus partes, resulta gravitante y un eje central sobre el que se rige el derecho del trabajo, en general. Aquello ha quedado plasmado en la serie de conversaciones y mesas desarrolladas al efecto. De hecho, "la 95o. reunión de la Conferencia Internacional del Trabajo adoptó la Recomendación núm. 198 sobre la relación de trabajo, culminando así una evolución de diez años, que conoció diversos avatares, alternativas y encares, y que tuvo además un episodio rele-

17 Por ejemplo, véase Mateo, José Antonio et al., "Precarización y fraude laboral en la industria pesquera marplatense. El caso de las 'cooperativas' de fileteado de pescado. Estado actual de la situación y evolución histórica de la rama, 1989-2010”, El estado de la clase trabajadora en la Provincia de Buenos Aires, La Plata, Ministerio de Trabajo de la Provincia de Buenos Aires, CEIL-PIETTE (Conicet), 2011, pp. 177-302. 
vante cuando en 1997 se aprobó el Convenio Internacional núm. 181 sobre agencias de empleo privadas, instancia que debe ser vista como parte de este proceso más general de regulación del trabajo prestado bajo modalidades atípicas y triangulares". ${ }^{18}$ Aquello sin perjuicio de que la OIT ha aprovechado esta instancia para cuestionarse internamente sobre sus propias funciones normativas, y las funciones y misión que ha de cumplir dicha organización internacional en materia normativa laboral. Tanto empleadores como trabajadores, a través de sus representantes, han tenido la oportunidad de discrepar en el ámbito público sobre los criterios restrictivos que muchas legislaciones nacionales han acogido para la determinación de la relación laboral, y han permitido que la OIT concluya en la adopción y promoción de un criterio amplio en la calificación de la relación laboral, en atención más bien a indicios de calificación, atendido lo restrictivo que puede resultar la mera aplicación del criterio de subordinación clásico. ${ }^{19}$ En relación a la mencionada recomendación OIT se ha destacado esencialmente que

...el contenido de esta recomendación comprende importantes orientaciones para implementación de políticas nacionales dirigidas hacia la protección de los trabajadores que se encuentran dentro de una relación de trabajo.

Brinda importante orientación sobre la definición de las categorías de los trabajadores que deben ser protegidos, la interrelación de diferentes normas internacionales, el fortalecimiento del diálogo social, a través de procesos de consulta y de negociación colectiva, para el establecimiento de medidas específicas en el ámbito nacional.

Especialmente establece que: una política nacional de protección de los trabajadores debe como mínimo luchar contra las relaciones de trabajo encubiertas para evitar que acuerdos contractuales generen desprotección en los trabajadores.

Comprende también una importante serie de consideraciones para que, desde la perspectiva de una política nacional, se defina con claridad los elementos de una relación de trabajo con base en la existencia de indicadores que denoten que el trabajo se realiza bajo subordinación o dependencia.

18 Barretto Ghione, Hugo, "La determinación de la relación de trabajo en la recomendación 198 y el fin del discurso único de la subordinación jurídica”, Revista Direito Unifacs, núm. 129, 2011.

19 Idem. 
Resalta la importancia del principio de "primacía de la realidad" para la resolución de controversias. ${ }^{20}$

Ahora bien, la Recomendación núm. 198 sobre la relación de trabajo ${ }^{21}$ en comento tiene un objeto íntimamente relacionado con el tema tratado en la presente investigación, cual es la proscripción de los encubrimientos ilícitos de la relación laboral por parte de los empleadores, para lo cual el Estado ha de velar por tomar las medidas tendientes a su vigilancia y sanción. Así, se ha indicado que:

...la recomendación establece una serie de lineamientos para asegurar la implementación de medidas que aseguren el cumplimiento efectivo de la ley a través del establecimiento de apropiados mecanismos de resolución de conflictos sobre la base de que estos sean rápidos, justos y eficientes.

Resalta el papel de la inspección del trabajo y la necesidad de considerar el aspecto de género al tratar la situación de las trabajadoras que no cuentan con protección laboral.

Indica directamente la necesidad de que a través del diálogo social y la negociación colectiva se establezcan, a nivel nacional, medidas que desincentiven la realización de este fraude. ${ }^{22}$

En un trabajo de investigación recientemente publicado por la OIT, ésta ha definido los deberes del Estado en materia de persecución y sanción a las situaciones de informalidad laboral y encubrimientos o simulaciones. Ha señalado en ese sentido que:

En este marco, el Estado debe tener un papel activo en campos que lo exigen, como:

a) las situaciones laborales legalmente ambiguas, que dan lugar a fraude empresarial mediante la simulación de relaciones de dependencia como si fueran autónomas (con base en la Recomendación 198 de OIT). Ello incluye también la distinción de relaciones semi-autónomas, en que el trabajador

20 Argueta R., Alejandro, El disfraz de la relación de trabajo en Guatemala, Guatemala, Central General de Trabajadores de Guatemala, 2008, p. 55.

21 Es preciso recordar en este acápite que la recomendación es un instrumento normativo no vinculante para los Estados parte de la OIT, a diferencia de los Convenios.

22 Argueta R., Alejandro, El disfraz..., op. cit., p. 56. 
aparentemente independiente sostiene su actividad en vínculos permanentes exclusivos o casi con un demandante;

b) las situaciones de tercerización (vía subcontratación de empresas y de utilización de agencias de trabajo temporal), que necesitan la recomposición de las nociones de representación (y ámbitos de negociación) a partir de las nuevas realidades de la configuración empresarial, en tanto los procesos productivos (como lo menciona el informe sobre Argentina) "han dislocado el sistema de representación tradicional, fragmentando el colectivo y generando una heterogeneidad normativa desigual". ${ }^{23}$

Las figuras de encubrimiento laboral no sólo han preocupado a la OIT, y la doctrina nacional en el ámbito del derecho individual del trabajo, sino que incluso se ha hecho una prevención y precaución en materia colectiva, como ocurre en el caso de México, por ejemplo. Así, la OIT ha reconocido que "en la región se encuentra un caso extremo, el de los sindicatos de simulación y los 'contratos de protección patronal' de México, que tienden a ser 'exportados' a otros países, producto de normativas que los estimulan indirectamente". ${ }^{24}$ Los contratos de protección patronal, y la situación de larga data histórica en México, con la sistemática vulneración de la libertad sindical por supuestos "representantes", en complicidad con el Estado, son una expresión manifiesta de la relevancia que puede adoptar la figura de la simulación en materia colectiva, sin embargo aquello no es el tema de esta investigación, que refiere más bien al ámbito individual. ${ }^{25}$

La preocupación en el ámbito internacional sobre la certeza y determinación de las partes del contrato de trabajo, y la calificación de la relación misma como una de naturaleza laboral, tiene en cada país su expresión propia, en atención a la realidad e idiosincrasia propia de cada Estado. Las figuras recurrentes a través de las cuales se aborda el problema son el "fraude a la ley", la "simulación" y el "abuso de derecho", sin embargo en pocos casos se ahonda en alguna distinción clara que permita diferenciar de manera independiente cada una de aquellas figuras doctrinarias.

\footnotetext{
23 Organización Internacional del Trabajo, Panorama laboral normativo. En materia de libertad sindical y negociación colectiva en américa latina y caribe, Brasil, 2016, p. 158.

24 Idem.

25 Para un análisis sobre los Contratos colectivos de protección, y las cláusulas de paz, véase De Buen Unna, Carlos, "Los contratos colectivos de trabajo de protección patronal en México”, Análisis politico, México, Fundación Friedrich Ebert, 2011.
} 
Se ha señalado en torno a la simulación, por ejemplo, que "la simulación del vínculo jurídico-laboral, se ha convertido, desafortunadamente, en un mal endémico creciente que requiere con urgencia, encontrar la vacuna o el antídoto para detener estas prácticas perniciosas de mala fe, tanto en el sector público como en el privado". ${ }^{26}$

$\mathrm{Al}$ analizar el rol de la figura de la simulación en las relaciones laborales contemporáneas, en México señala Lastra Lastra que:

...los trabajadores exangües por tantas penurias, enfrentan ahora la escasez, clandestinidad, precariedad y simulación que son la mácula predominante en el mundo del trabajo, ante las paupérrimas expectativas que ofrece la economía formal.

En la simulación, el fin típico del negocio diverge de la causa concreta o propósito de las partes, quienes pretenden crear una mera apariencia. Los sujetos "ocultan bajo la apariencia de un contrato, un propósito negocial distinto". Con la finalidad de "no celebrar negocio alguno (simulación absoluta) o celebrar otro distinto al aparente (simulación relativa)".

La afinidad del contrato de trabajo con otras figuras contractuales, permite que algunas relaciones personales queden encuadradas en figuras civiles (contrato de prestación de servicios profesionales) o mercantiles (comisión mercantil). ${ }^{27}$

En argentina, Cavalloti señala a propósito de la diferencia entre Fraude a la ley, y la simulación, que

Podemos señalar entonces que la simulación posee características que la distinguen del fraude, a saber:

- Supone un acuerdo entre partes.

- No se establece mediante omisión o ignorancia, sino que claramente refleja la intención de infringir la Ley.

- Puede mediar o no daño a terceros.

- Disconformidad entre la voluntad y la declaración.

La conformidad de los trabajadores ante el acuerdo entre las partes no constituirá un atenuante para la sanción del empleador. El principio

26 Lastra Lastra, José Manuel, "La buena fe en el trabajo; ¿un principio que se difumina?”, Letras juridicas: revista de los investigadores del Instituto de Investigaciones Juridicas U. V., núm. 8, 2003, pp. 37-77.

27 Ibidem, p. 43. 
de irrenunciabilidad da consistencia a esta cláusula, ya que bajo ninguna circunstancia el empleado podrá renunciar a sus derechos ni a las normas vigentes en los Convenios Colectivos de Trabajo. Las disposiciones corresponden al Orden Público. ${ }^{28}$

Precisamente la relevancia de la identificación de las figuras en comento atiende al efecto del develamiento de la realidad oculta tras la mera forma, pues, "si se develara el acto simulado o fraudulento, serán aplicadas las normas que regulan la forma contractual fáctica", ${ }^{29}$ y para algunos ordenamientos, "será declarada la nulidad de los actos simulados o fraudulentos, aplicándose la norma correspondiente a la relación de hecho que vincula al trabajador con el empleador". ${ }^{30}$

En Perú, por ejemplo, se ha abordado el análisis de la figura de simulación en materia de modalidad del contrato, en cuanto determinación de la duración de la misma, atendiendo por tanto a otro nivel de relevancia e incidencia de las figuras de simulación y fraude, ahora existiendo efectivamente contrato de trabajo suscrito. Al respecto se ha señalado que

...cuando se califica que estamos ante una simulación o fraude en la contratación, es afirmar que si bien se ha cumplido con las formalidades de una contratación modal, estamos por su naturaleza jurídica frente un contrato a tiempo indeterminado.

Es evidente que resulta muy difícil acreditar al momento de la celebración del contrato modal o de su redacción, que éste obedece a una simulación o fraude; sin embargo, mientras se vaya prestando el servicio podría probarse dicha desnaturalización. La causa invocada en el contrato puede obedecer a una modalidad recogida en la ley, pero la prestación que realiza el contratado es distinta a la pactada y de naturaleza indeterminada. ${ }^{31}$

En Venezuela, por su parte, Arévalo ha señalado que

...el acto mediante el cual un empresario o patrono, sea este privado o público - el Estado-, incurre en lo que se conoce como fraude laboral y, que

28 Cavallotti, Valentina, La locación de servicios como fraude laboral, Argentina, Universidad Siglo 21, 2015, p. 58, disponible en: https:// repositorio.uesiglo21.edu.ar/bitstream/handle/ ues21/12870/CAVALLOTTI\%20Valentina.pdf?sequence=1, consultado el 10 de agosto de 2017.

29 Ibidem, p. 60.

30 Idem.

31 Servat Pereira de Sousa, Roberto Juan, "Causas de desnaturalización de los contratos de trabajo sujetos a modalidad en la legislación peruana”, Revista Peruana de Derecho de la Empresa, Perú, núm. 58, año XIX, enero de 2005, p.10. 
el mismo adquiere la forma de relaciones laborales encubiertas, sin ningún tipo de apego al Clásico e histórico contrato de trabajo; constituye una de las alteraciones más notorias de los últimos tiempos en el mundo del trabajo.

El razonamiento neoliberal es concluyente: este derecho del trabajo, protector y de férrea intervención estatal, no se adecua a la época globalizadora. Flexibilizar y desregular la relación laboral, es un imperativo. La salida idónea: transformar al trabajador en "empresario". 32

Específicamente en relación al fraude a la ley, a propósito del fraude laboral, se ha señalado que para cometer de forma genérica fraude a la ley es preciso que concurra:

a) Norma jurídica imperativa u obligatoria;

b) Utilización de un medio legalmente eficaz; e

c) Intención de eludir la norma imperativa, como elemento subjetivo que caracteriza este tipo de fraude.

En otras palabras, el acto fraudulento se comete mediante el empleo de otros dispositivos legales que permiten lograr el contenido que prohíbe la ley vulnerada. ${ }^{33}$

\section{En algunos países}

...se incluye la figura del "fraude laboral" cuando una empresa principal busque eludir su responsabilidad a través de otras empresas subordinadas, como ocurre en República Dominicana, y extienden la solidaridad entre empresas con estas características aun cuando no exista tal intención ('fraude laboral'), como es el caso de Brasil. En algunas legislaciones se establece la unidad de empresa y se posibilita la equiparación de condiciones de trabajo cuando se cumplen dos requisitos: dependencia económica o jurídica entre la empresa principal y la subordinada y cuando todas realizan actividades similares, conexas o complementarias (Colombia). ${ }^{34}$

32 Romero Milano, Antonio, "Relaciones laborales encubiertas en Venezuela", Compendium: Revista de investigación cientifica, núm. 20, 2008, pp. 73-87.

33 Cavallotti, Valentina, La locación de servicios..., cit., p. 59.

34 Ruiz Medrano, Salvador Francisco y Cisneros Silva, Guadalupe. "El outsourcing desde la perspectiva jurídica, laboral y administrativa de México y el mundo y su problemática actual", Ponencia presentada en XV Congreso Internacional de Investigación en Ciencias Administrativas, Veracruz, 2011, disponible en: http:// acacia.org.mx/busqueda/pdf/01_03_Outsourcing.pdf, consultada el 9 de agosto de 2017. 
Por otra parte, en la materia se ha reconocido explícitamente la importancia del principio de realidad en derecho comparado, como eje central sobre el que se erige el derecho del trabajo, y que opera como herramienta idónea en el esclarecimiento en la determinación jurídica de una situación contractual de dicha naturaleza. Muñoz, a propósito del análisis de la legislación positiva colombiana concluye, por ejemplo, que "los estudiosos del Derecho en la doctrina manifiestan que independientemente de la apariencia que muestre el empleador para tratar de evadir sus responsabilidades derivadas del verdadero contrato de trabajo se tendrán en cuenta las verdaderas y reales características del contrato de trabajo". ${ }^{35}$

El escenario global, como hemos expuesto, ha analizado el problema de la presencia de simulación, fraude laboral, informalidad, y en general, ocultamiento de las partes de la relación laboral (en particular del empleador), o de la sujeción de la relación jurídica al estatuto laboral protector. Sin embargo, y conforme se desprende tanto de los análisis nacionales expuestos, como de los pronunciamientos OIT, es posible efectuar distinciones a efectos de clarificar el problema.

En primer lugar, podemos distinguir en los problemas de simulación, fraude, o figuras de encubrimiento de la relación jurídica laboral, tanto en el ámbito individual, como el ámbito colectivo. En este último ámbito, que no es el propio de la presente investigación, podemos diferenciar a su vez en las formas de simulación, fraude o encubrimiento en a) la constitución del órgano colectivo sindical (sindicatos fraudulentos), o bien, b) en la simulación relativa o absoluta respecto de un instrumento colectivo que vincule al sujeto colectivo con el empleador pertinente, como ocurre en el caso de México con los contratos colectivos de protección.

Por otra parte, y aquí cobra relevancia el tema que será tratado en las líneas siguientes, es posible en materia individual reconocer ámbitos de simulación absoluta, cuando estamos en presencia de la celebración de un acto comercial o civil, y en realidad, conforme a los hechos, se trata de una relación laboral, por lo que en realidad el acto jurídico íntegro resulta inadecuado con la realidad y la intención de las partes. Pero además, es posible descubrir situaciones de simulación relativa, cuando por ejemplo, existiendo un contrato de trabajo se estipula una cláusula que determine que el cargo es "A", pero el trabajador desempeñará en los hechos

35 Muñoz, A., "Aplicación de la primacía de la realidad sobre la formalidad en los contratos de trabajo", Pensamiento Americano, Barranquilla-Medellín, vol. 5, núm. 8, enero-junio de 2012, pp. 9-14. 
funciones de "B", o cuando se contrate a un trabajador a plazo, de manera sucesiva, cuando en realidad la intención de las partes ha sido en realidad la contratación indefinida del trabajador, y además así lo estipula la ley (estaríamos en este caso más cercanos a una figura de fraude laboral, que una de simulación).

Sin embargo, en el ámbito del derecho individual del trabajo una forma de encubrimiento específica, que no ha sido abordada con la profundidad esperada, se trata de la simulación relativa en cuanto a la persona de los contratantes. En particular, en materia laboral hablamos de aquellos casos en que un empleador (una razón societaria) contrata formalmente a un trabajador, y aparece como su empleador en su contrato de trabajo escrito, sin embargo, en la realidad, dicho trabajador se desempeña para otro u otras sociedades, íntimamente relacionadas con ésta última, lo que amerita que todas, en conjunto, sean consideradas como un sólo empleador para efectos laborales. No hablamos de la cesión ilegal de trabajadores, sino más bien de la operación de los denominados boldings empresariales, o grupos de empresas, que contratarían a trabajadores con sólo una de sus razones sociales, en perjuicio de la cautela crediticia de los trabajadores. Se trata de empleadores encubiertos en un grupo.

Es precisamente este último caso sobre el que versa la presente investigación, en cuanto el legislador chileno ha dispuesto una norma sancionatoria específica para aquellos casos en que se logre descubrir una situación de encubrimiento patronal, mediante simulación o subterfugio. Ha establecido al respecto una sanción especial, cuya determinación concreta ha de ser evaluada judicialmente. Con la misma reforma se ha sancionado las conductas de simulación y subterfugio a propósito sólo de la figura que hemos descrito genéricamente, esto es, cuando concurriría la simulación o subterfugio con la finalidad del ocultamiento de una razón social que termina siendo judicialmente declarada como un único empleador junto a otras empresas. Por lo mismo, no sanciona la simulación, fraude o subterfugio en la contratación individual de trabajadores, cuando, por ejemplo, contrata conforme a instrumento civil a un trabajador para que le preste servicios en la calidad de prestador de servicios civiles, eludiendo así la aplicación del ordenamiento laboral. Para aquellos casos en que la contratación civil, o la nula contratación, termine siendo judicialmente declarada como contratación laboral, no existe sanción alguna contemplada en la ley.

En Chile se ha reconocido también el problema de determinación del sujeto pasivo de las obligaciones laborales, y ante el auge de la descentralización productiva y la explosión de fundaciones societarias los trabajadores han quedado expuestos no tan sólo a la informalidad, sino a una formalidad ineficaz, 
y carente de garantía crediticia, en donde los patrimonios obligados resultan ocultarse de la persecución laboral, sea para efectos colectivos, sea para efectos individuales de la relación de trabajo.

Ahora bien, ¿cuáles son las figuras sancionatorias que ha previsto el legislador chileno?, ¿cuáles son las sanciones aplicables, ¿quién es el agente estatal con competencia para la aplicación de dichas sanciones?, ¿qué contrato es el que ha de someterse a un examen de licitud, y respecto de los cuales contratos se hará el análisis pertinente?, ¿es el contrato de trabajo suscrito entre las partes el simulado?, de ser ése el caso, ¿concurren los requisitos de la simulación respecto de los contratantes, o más bien la expresión simulación es usada en un sentido no técnico? Éstas son algunas de las cuestiones que pretendemos abordar en las líneas que siguen.

\section{EL INTENTO LEGISLATIVO DE OTORGAR UNA SOLUCIÓN}

El día nueve de julio del año 2014 entra en vigencia la Ley 20.760, que "Establece el supuesto de multiplicidad de razones sociales consideradas un solo empleador y sus efectos". 36

36 La ley señala: "Artículo único. Modifícase el Código del Trabajo en la siguiente forma:

1) En el artículo 3o::

a) Reemplázase, en el inciso tercero, la frase «bajo una dirección» por 1«bajo la dirección de un empleadon».

b) Sustitúyese el inciso final por los siguientes incisos cuarto, quinto, sexto, séptimo y octavo: «Dos o más empresas serán consideradas como un solo empleador para efectos laborales y previsionales, cuando tengan una dirección laboral común, y concurran a su respecto condiciones tales como la similitud o necesaria complementariedad de los productos o servicios que elaboren o presten, o la existencia entre ellas de un controlador común.

La mera circunstancia de participación en la propiedad de las empresas no configura por sí sola alguno de los elementos o condiciones señalados en el inciso anterior.

Las empresas que cumplan lo dispuesto en el inciso cuarto serán solidariamente responsables del cumplimiento de las obligaciones laborales y previsionales emanadas de la ley, de los contratos individuales o de instrumentos colectivos.

Las cuestiones suscitadas por la aplicación de los incisos anteriores se sustanciarán por el juez del trabajo, conforme al Párrafo 3o. del Capítulo II del Título I del Libro V de este Código, quien resolverá el asunto, previo informe de la Dirección del Trabajo, pudiendo requerir además informes de otros órganos de la Administración del Estado. El ejercicio de las acciones judiciales derivadas de la aplicación del inciso cuarto, así como la sentencia definitiva respectiva, deberán, además, considerar lo dispuesto en el artículo 507 de este Código.

Los trabajadores de todas las empresas consideradas como un solo empleador podrán constituir uno o más sindicatos que los agrupen, o mantener sus organizaciones existentes; podrán, asimismo, negociar colectivamente con todas las empresas que han sido consideradas como un empleador, o bien con cada una de ellas. Los sindicatos interempresa que agrupen exclu- 
La autonomía privada se ha erigido históricamente como uno de los pilares (o principios) fundamentales de todo ordenamiento jurídico occidental.

sivamente a trabajadores dependientes de empresas que hayan sido declaradas como un solo empleador podrán presentar proyectos de contrato colectivo, siendo obligatorio para el empleador negociar con dichos sindicatos. En todos estos casos, la presentación y tramitación de los proyectos de contrato colectivo se regirán por las normas establecidas en el Capítulo I del Título II del Libro IV de este Código».

2) Sustitúyese el artículo 507 por el siguiente:

«Artículo 507. Las acciones judiciales derivadas de la aplicación del inciso cuarto del artículo 3o. de este Código podrán ser ejercidas por las organizaciones sindicales o trabajadores de las respectivas empresas que consideren que sus derechos laborales o previsionales han sido afectados. Estas acciones podrán interponerse en cualquier momento, salvo durante el período de negociación colectiva a que se refiere el Capítulo I del Título II del Libro IV de este Código; si el procedimiento judicial iniciado sobrepasa la fecha de presentación del proyecto de contrato colectivo, los plazos y efectos del proceso de negociación deberán suspenderse mientras se resuelve, entendiéndose para todos los efectos legales prorrogada la vigencia del instrumento colectivo vigente hasta 30 días después de ejecutoriada la sentencia, día en que se reanudará la negociación en la forma que determine el tribunal, de acuerdo con lo dispuesto en la ley. La sentencia definitiva que dé lugar total o parcialmente a las acciones entabladas deberá contener en su parte resolutiva:

1. El pronunciamiento e individualización de las empresas que son consideradas como un solo empleador para efectos laborales y previsionales, conforme a lo señalado en el inciso cuarto del artículo 3o. de este Código.

2. La indicación concreta de las medidas a que se encuentra obligado el empleador dirigidas a materializar su calidad de tal, así como aquellas destinadas al cumplimiento de todas las obligaciones laborales y previsionales y al pago de todas las prestaciones que correspondieren; bajo apercibimiento de multa de 50 a 100 unidades tributarias mensuales, la que podrá repetirse hasta obtener el debido cumplimiento de lo ordenado.

3. La determinación acerca de si la alteración de la individualidad del empleador se debe o no a la simulación de contratación de trabajadores a través de terceros, o bien a la utilización de cualquier subterfugio, ocultando, disfrazando o alterando su individualización o patrimonio, y si ello ha tenido como resultado eludir el cumplimiento de las obligaciones laborales y previsionales que establece la ley o la convención. Si así lo determina, deberá señalar de manera precisa las conductas que constituyen dicha simulación o subterfugio y los derechos laborales y previsionales que por esta vía se hubieren vulnerado, debiendo aplicar al infractor una multa de 20 a 300 unidades tributarias mensuales. En estos casos, será aplicable a las multas señaladas lo dispuesto en el inciso quinto del artículo 506 de este Código.

Quedan comprendidos dentro del concepto de subterfugio referido en el párrafo anterior, cualquier alteración de mala fe realizada a través del establecimiento de razones sociales distintas, la creación de identidades legales, la división de la empresa, u otras que signifiquen para los trabajadores disminución o pérdida de derechos laborales individuales o colectivos, en especial entre los primeros las gratificaciones o las indemnizaciones por años de servicios y entre los segundos el derecho a sindicalización o a negociar colectivamente.

La sentencia definitiva se aplicará respecto de todos los trabajadores de las empresas que son consideradas como un solo empleador para efectos laborales y previsionales. 
En el contexto del ejercicio de la autonomía privada, en un segundo nivel, se ha consagrado también la libertad de asociación de las personas privadas, en un primer momento, como personas naturales. El reconocimiento que el ordenamiento jurídico les otorga se consolida paradigmáticamente en la facultad de crear personas jurídicas ${ }^{37}$ para actuar en el mundo del derecho, quienes poseerán una razón social propia, y un patrimonio diferente de quienes la constituyen. A su vez, dichas asociaciones pueden suscribir contratos con otras asociaciones reconocidas jurídicamente o, en virtud también del ejercicio de la autonomía privada, pueden alzar la creación de nuevas personas jurídicas.

Hasta este punto, no hay más que una enunciación saludable y legitima de los derechos subjetivos de toda persona natural. Sin embargo, es precisamente en el límite de la legitimidad en donde cobra relevancia jurídica su regulación (en una situación no patológica, estamos sólo ante un ejercicio legítimo de la libertad de los particulares). El ejercicio malicioso de la libertad de asociación surgió entre los particulares y precisamente tenía como objetivo la evasión de deberes y obligaciones con otros particulares o con el propio Estado, como por ejemplo ocurre con las obligaciones tributarias o laborales.

Precisamente es en el último caso enunciado en donde cobra relevancia la preocupación del legislador chileno. La utilización maliciosa de la creación de personas jurídicas, su organización y dinámicas de funcionamiento, habían estado generando sistemáticamente un perjuicio a los trabajadores, eludiendo sus obligaciones legales o convencionales. Si bien los trabajadores prestaban servicios materialmente para alguna empresa en particular, el ordenamiento jurídico chileno le permitía ser contratado por una persona jurídica diferente. Los resultados perniciosos de la utilización de una figura tal son variados, entre los cuales encontramos, debilitamiento de la fuerza sindical y colectiva, pérdida de solvencia de los obligados laboralmente, evasión de responsabilidades por actuaciones negligentes o culpables por parte del empleador efectivo, entre otras.

Las acciones a que se refieren los incisos precedentes podrán ejercerse mientras perdure la situación descrita en el inciso cuarto del artículo 3o. de este Código, sin perjuicio de lo dispuesto en el inciso segundo del presente artículo»".

37 Cada una con un número de identificación individual con fines tributarios (RUT: Rol Único Tributario). Precisamente de ahí la denominación de ley "Multirut". 
El gobierno, en efecto, hasta el día de hoy sostiene públicamente en su página Web las razones que justificaron la dictación de la ley Multirut, señalando al efecto que era necesaria porque:

...la división de un negocio en múltiples empresas está provocando, en muchos casos, el debilitamiento o imposibilidad de ejercer algunos derechos laborales, como la libertad sindical, la negociación colectiva y derechos individuales como el derecho al pago de indemnizaciones por años de servicio. $\mathrm{Al}$ regular el uso Multirut se "empareja la cancha" entre trabajadores y empleadores ya que la libertad de organización de las empresas no puede estar por sobre los derechos laborales de sus trabajadores. ${ }^{38}$

La Ley Multirut, precisamente pretende sancionar la creación de múltiples razones sociales, personas jurídicas, y RUT's, que tenían una finalidad maliciosa, o incluso, que sin tener una finalidad intencionalmente perjudicial para los trabajadores, tenían un resultado pernicioso para la pretensión protectora del derecho del trabajo, en cuanto eludían la declaración de una relación laboral, o entrampaban la determinación del empleador en tanto sujeto pasivo de las obligaciones laborales en particular.

El profesor Ugarte realizó una lectura crítica del proyecto de ley que pretendió otorgar una solución certera a los casos de grupos de empresa que parecían tener la intención de defraudar laboralmente a los trabajadores, y es ese sentido afirmó que:

...hace un tiempo diversas empresas, especialmente de supermercados y del retail, se inventaron un fraude que consistía en dividir la empresas en una pluralidad de razones sociales — en algunos casos, por cientos—, sosteniendo que por ese solo hecho — que sus abogados redactasen cientos de papeles-, cada una de esas razones y los respectivos trabajadores adscritos a ellas, debían ser considerados un empleador distinto para efectos de la formación de sindicatos y de negociación colectiva.

Como se ve, la finalidad de este fraude era obvia: dividir a los trabajadores para que no puedan negociar colectivamente en un solo proceso con fuerza y unidad. A pesar de trabajar para el mismo empleador.

38 Gobierno de Chile, Las claves para entender el MultiRut, Chile, Gobierno de Chile, 2014, disponible en: http:/ / wmw.gob.cl/2014/07/04/ las-claves-para-entender-el-multirut/, consultado el 18 de abril de 2017. 
En un país en serio, esto no habría pasado de ser un fraude reprimido por los propios sindicatos y la justicia laboral. Pero estamos en Chile y ese fraude se ha sostenido, tanto por la extrema debilidad sindical como por la debilidad de las autoridades.

Ni este proyecto ni el del gobierno de Piñera aceptaron el punto básico del tema: que se trata de un fraude laboral que busca esconder detrás de la un pluralidad de personas jurídicas a un solo empleador.

La solución no es, por tanto, darle garantías al que hace el fraude, ni ponerle trabas al afectado. $\mathrm{Y}$ es eso, precisamente, lo que hace el proyecto recién presentado. ${ }^{39}$

Pero entonces podía pensarse que si bien la solución no la otorgaba el texto normativo expreso, podría resultar ser el juzgador, en el caso concreto, quién hubiese terminado por solucionar cualquier uso malicioso de las formas societarias artificiales. Sin embargo, parecía que dicha esperanza no resultaba suficientemente fundada. En ese sentido el profesor Ugarte también señalaba que:

La Corte Suprema ha resuelto el problema de la tensión entre la multiplicidad de personas jurídicas (razones sociales), y la existencia de una sola estructura de mando y subordinación (un empleador), en favor de las primeras, validando la práctica de que la división de la sociedad se traduzca en una seria afectación de los derechos colectivos del trabajo. Todo de la mano de la particular interpretación del artículo 3o. del Código del Trabajo, que pone el acento en la "individualidad legal determinada", y convenientemente olvida el resto de la definición contenida en dicho artículo.

En este punto, cabe preguntarse: ¿en base a qué razonamiento la CS soslaya en materia colectiva el principio de primacía de la realidad y de la unidad económica que ella misma ha utilizado frecuentemente en materia de derechos laborales individuales, y en vez de levantar el velo corporativo, decide más bien protegerlo o reforzarlo? ${ }^{40}$

A pesar de las afirmaciones previas, así como de las críticas evaluaciones legales y jurisprudenciales que desde la segunda mitad de la década de los dos

39 Ugarte, José Luis, "Multirut. Mortalmente parecidos", El Mostrador, Chile, 2014, disponible en: http:// mmm.elmostrador.cl/ noticias/opinion/2014/04/24/ multirut-mortalmente-parecidos/, consultado el 23 de marzo de 2017.

40 Ugarte, José Luis, "La actual Corte Suprema y su particular concepto de empresa para efectos de la negociación colectiva”, La Semana Jurídica, núm. 382, 2008, p. 2. 
mil la doctrina laboralista venía realizando, había quienes conservaban la suficiente mesura para analizar las posibles modificaciones legislativas con cierta perspectiva. En ese sentido, Palomo avizoraba entonces que la solución de los problemas que empezaban a plantearse en el análisis de grupos de empresa

...no pasa por el simple desconocimiento de la personalidad jurídica de los sujetos que conforman el grupo, sino por comprender que ella no puede significar un obstáculo insoslayable al ejercicio de los derechos laborales. Asimismo, la solución no puede construirse sobre una concepción que considere a los grupos de empresas como un centro de sospechas, sino que debe dar respuestas a los problemas concretos que la existencia de dichos grupos plantea en el orden laboral, tanto en los casos de fraude como en los muchos supuestos de organización empresarial lícita. ${ }^{41}$

La reforma introducida a través de la denominada "Ley Multirut" pretendía subsanar la problemática plantada, estableciendo a través de los artículos 3o. y 507 del Código del Trabajo el sujeto legitimado activamente para accionar, solicitando la declaración de empleador único por existir una dirección laboral común entre dos o más empresas o razones sociales y concurran a su respecto condiciones tales como la similitud o necesaria complementariedad de los productos o servicios que elaboren o presten, o la existencia entre ellas de un controlador común, ${ }^{42}$ bajo la idea de que las

41 Palomo Vélez, Rodrigo I., "Los grupos de empresas en el derecho chileno del trabajo", Revista Ius et Praxis, vol. 12, núm. 2, 2006, pp. 399-406.

42 "La dirección laboral común debe siempre debe estar presente junto a otras condiciones, que no necesariamente son las enumeradas en el artículo 3o. inciso 4o. del Código del Trabajo. Es así, como se está ante la presencia de requisitos que deben concurrir en forma copulativa, por lo que si falta uno de ellos o ambos no podrá determinarse que dos o más empresas son un solo empleador.

Conclusión que resulta correcta, en nuestra opinión, debido a que si el legislador hubiese exigido única y exclusivamente la concurrencia de la dirección laboral común para que dos o más empresas fueran declaradas como empleador común habría bastado con incorporar en el inciso 4o. del artículo 3o. del Código del Trabajo solamente la siguiente frase: «dos o más empresa serán consideradas como un solo empleador para efectos laborales y previsionales cuando tengan una dirección laboral común», habiendo sido inútil agregar la frase: «Y concurran a su respecto condiciones tales como la similitud y necesaria complementariedad de los productos o servicios que elaboren o presten, o la existencia entre ellas de un controlador común»: Si la Ley núm. 20.760 decidió incorporar en el artículo 3o. inciso 4o. o ambas frases conjuntamente unidas bajo la conjunción copulativa «y» fue precisamente porque exige que para estar en 
figuras jurídicas utilizadas por las empresas devienen irrelevantes ante el objetivo proteccionista que otorga el derecho del trabajo, que habría de situar su mirada preeminentemente en la realidad efectiva (conforme al principio de primacía de la realidad ${ }^{43}$ antes que sobre la elucubración jurídica que pudo haberse establecido para fines tributarios, comerciales, o de otro tipo, ${ }^{44}$ que no pasaría de ser un mero abuso de la "formalidad". Reforma que políticamente ni siquiera pudo satisfacer a sus propios gestores, pues tal como señala Ugarte "el proyecto estrella del gobierno en materia laboral —más bien el único proyecto- no convenció siquiera a los propios funcionarios del Ministerio del Trabajo ni de la Inspección del Trabajo, que emitieron una declaración diciendo que era malo y equivocado". ${ }^{45}$

La norma contenida en el artículo 507 del Código del Trabajo ha modificado la técnica legislativa que hasta su emisión el legislador había plasmado en nuestro Código del Trabajo proscribiendo la simulación laboral y el subterfugio. El legislador conserva una apreciación de reproche ante las configuraciones jurídicas idóneas que comprometerían la certeza jurídica en la contratación laboral, sin embargo, dicho reproche normativo es consagrado de manera tal que su tipificación resulta constituir figuras sancionatorias secundarias y subsidiarias a una eventual alegación (o pretensión) principal de

presencia del empleador común debe concurrir la dirección laboral común y otras condiciones como las que enumera u otras, de lo contrario, no se justifica la segunda parte del párrafo luego de la conjunción «y»". Fernández Toledo, Raúl, "Empleador único (unidad económica: requisitos de configuración, alcance de la exigencia dirección laboral común y procedencia de la acción de subterfugio. Comentario a la sentencia de Multirut de la Corte de Apelaciones de Concepción, Rol Reforma Laboral núm. 76-2015”. Revista chilena de derecho del trabajo y de la seguridad social, vol. 6, núm, 11, 2015, pp. 195-202.

43 "El principio de primacía de la realidad significa que en caso de discordancia entre lo que ocurre en la práctica y lo que surge de documentos o acuerdos, debe darse preferencia a lo primero, es decir a lo que ocurre en el terreno de los hechos" Plá Rodríguez, Américo, Los principios del derecho del trabajo, 3a. ed., Buenos Aires, De palma, 1998, p. 313.

44 "Este criterio se fundamenta en la inferioridad del trabajador, quien puede ser objeto de abusos que sólo pueden subsanarse con la primacía de los hechos sobre las formas, las formalidades o las apariencias. En materia laboral importa lo que ocurre en la práctica más que lo que las partes hayan pactado en forma más o menos solemne o expresa, o lo que luzca en documentos, formularios e instrumentos de control". Gamonal, Sergio, Fundamentos de derecho laboral, Santiago de Chile, Legal Publishing Chile, Thomson Reuters, 2014, pp. 178-179.

45 Ugarte, José Luis, "Ley de Multirut: de vuelta a los gloriosos 90”, El mostrador, 23 de junio de 2014, disponible en: http:/ / www.elmostrador.cl/noticias/opinion/2014/06/23/ley-de-multirutde-vuelta-a-los-gloriosos-90/, consultado el 15 de noviembre de 2016. 
único empleador. Lo anterior implica la configuración de análisis dogmático de una serie de nuevas características de estas figuras, que pretendemos exponer críticamente en las líneas que siguen.

Debo anticipar desde ya que en las siguientes líneas no se encontrarán mayores ahondamientos argumentativos sobre la juridicidad de la modificación legislativa que autorizan la declaración de un sólo empleador ante la existencia de una dirección laboral común, ni menos cuáles son los requisitos de su concurrencia, o el eventual conflicto ius fundamental que podríamos plantear si se pretende efectuar una lectura crítica de la teoría del levantamiento del velo corporativo ${ }^{46} \mathrm{y}$ en defensa de la legalidad y vigencia de la expresión "individualidad determinada". Todos aquellos ámbitos de estudio ameritan, por sí mismos, una dedicación doctrinaria independiente, y refieren más bien a un estatus lógico previo a la materia sobre la que versa ésta investigación. En las siguientes páginas pretendemos avocarnos sobre todo a las figuras de simulación y subterfugio contenidas en el artículo 507 del Código del Trabajo, y no así a los alcances de lo dispuesto en el artículo 3o. de dicho cuerpo legal.

Para desarrollar nuestra investigación dividiremos el contenido de la exposición en una serie de secciones que, espero, puedan ser comprendidos en una línea argumentativa continua: a) sobre el artículo 507 del Código del Trabajo actualmente vigente; b) simulación y subterfugio: problemas de interpretación; c) consecuencias de la nueva forma de regulación; d) la sanción contemplada en la ley como ejercicio del ius puniendi estatal a través del Estado juez; e) conclusiones.

\section{SOBRE EL ARTíCUlO 507 DEL CÓDigO} DEL TRABAJO CHILENO ACTUALMENTE VIGENTE

El 9 de julio de 2014 entró en vigencia la Ley 20.760, que "Establece supuesto de multiplicidad de razones sociales consideradas un solo empleador y sus efectos". Esta ley pretende otorgar legislativamente una vía de

46 Ribera Neumann, Teodoro, "La protección constitucional de la empresa: la individualidad determinada y la teoría del levantamiento del velo", Sentencias Destacadas 2006, Ediciones Libertad y Desarrollo, Santiago de Chile, 2007, pp. 275-298. 
solución a los problemas de determinación jurídica del sujeto empleador ante situaciones difusas, creación maliciosa de grupos de empresas, ${ }^{47} \mathrm{o}$ dinámicas societarias maliciosas que incluyen fusiones, divisiones, absorciones, o incluso la cesión ilegal de trabajadores, ${ }^{48}$ y todas aquellas situaciones enfrentadas a las dificultades que plantea la determinación del concepto de empleador, aunque para algunos dicha disquisición dogmática no resulte de mayor trascendencia. ${ }^{49} \mathrm{Ha}$ sido amplio el debate que se ha suscitado hasta el momento en torno a la delimitación-distinción de los conceptos de empleador y empresa, ${ }^{50}$ particularmente a propósito de la expresión "individualidad legal determinada" 51 contenida en el artículo 3o. inciso 3o. del Código del Trabajo, el cual llegó incluso a ser expuesto en materia de constitucionalidad ante el Tribunal Constitucional, que terminó resolviendo sin

47 "Los grupos de empresas están formados por sociedades que, siendo formalmente independientes, actúan sin embargo bajo una dirección económica, originando una separación entre la realidad material y las formas jurídicas". Rojas Miño, Irene y Aylwin Chiorrini, Andrés, Los grupos de empresas en el derecho chileno del trabajo, Chile, Editorial LexisNexis, 2006, p. 25.

$48 \mathrm{Al}$ respecto, en España se ha señalado precisamente que el indicio de acertamiento de una situación de cesión ilegal de trabajadores se presenta con ocasión de la actuación fraudulenta del contratante, y así lo han comprendido los tribunales de dicho país. Martínez Garrido, Luis Ramón, "Contratas, cesión ilegal de trabajadores y cooperativas de trabajo asociado", Revista del Ministerio de Trabajo y Asuntos Sociales, núm. 38, 2002, pp. 229-239.

49 Ugarte, José Luis, El nuevo derecho del trabajo, Santiago de Chile, Editorial Universitaria, 2004, pp. 67 y ss.

50 López Fernández, Diego, La empresa como unidad económica, 2a. ed., Thomson Reuters, 2015, pp. 22-31.

51 Señala Gamonal al respecto que "Lamentablemente, dado el excesivo formalismo jurídico existente en nuestra cultura jurídica, una parte importante de la jurisprudencia judicial y administrativa se inclinó por entender que la frase 'individualidad legal determinada' aludía a una única individualidad jurídica de la empresa. Al respecto, la doctrina laboral enfatizó lo limitado de esta concepción, señalando que la individualidad legal pareciera vincularse más con el conjunto de elementos que concurren a ella antes que a una cuestión de forma y, por lo tanto, cuando encontremos recursos organizados para ciertos fines y ordenados por una dirección, siendo identificables como una unidad, estaremos ante una empresa laboral". Gamonal, Sergio, “Grupos de empresa y derecho laboral chileno. Tensiones y problemas”, en Rojas Miño, Irene y Aylwin Chiorrini, Andrés, Los grupos de empresas en el derecho chileno del trabajo, Chile, LexisNexis, 2006, p. 121. En el mismo sentido, véase Tapia, Francisco, "El concepto de empresa y los derechos sindicales en el derecho chileno del trabajo", Estudios en homenaje al profesor William Thayer A., Santiago de Chile, Sociedad Chilena de Derecho del Trabajo y de la Seguridad Social, 1998, p. 227. Una opinión crítica de la posición dogmática antes planteada se puede encontrar en Palavecino Cáceres, Claudio, "El concepto de empresa y su problemática". Revista Laboral Chilena, julio, 2008, pp. 80-85. 
pronunciarse por el fondo, sino más bien por una formalidad, pero que suscitó una posibilidad de exposición de los argumentos a favor y en contra de la relevancia de la expresión citada. ${ }^{52}$

Pero, ¿por qué resulta relevante la distinción entre empresa y empleador, y la delimitación de cada uno de dichos conceptos? Resulta que conforme a la configuración jurídica de la relación laboral las partes constitutivas de ésta son exclusivamente "el trabajador", por una parte, y "el empleador", por otra. Pareciera que hasta aquí fuese evidente la aseveración planteada, sin embargo al analizar su eventual aplicación casuística nos enfrentamos a una realidad compleja en la que la terminología utilizada resulta, a lo menos, imprecisa.

Según el propio artículo 3o. del Código del trabajo, trabajador es "toda persona natural que preste servicios personales, intelectuales o materiales de una o más personas en virtud de un contrato de trabajo", y, por otro lado, empleador es "la persona natural o jurídica que utiliza los servicios intelectuales o materiales de una o más personas en virtud de un contrato de trabajo". Pero a su vez, el mismo precepto añade un tercer concepto e indica que "Para los efectos de la legislación laboral y de seguridad social, se entiende por empresa toda organización de medios personales, materiales e inmateriales, ordenados bajo la dirección de un empleador, para el logro de fines económicos, sociales, culturales o benéficos, dotada de una individualidad legal determinada".

El problema es que dichas definiciones típicas abstractas (como cualquier otra abstracción de esta clase) son altamente indeterminadas, y resulta complejo su análisis desde un punto de vista dogmático, ${ }^{53}$ y más aún para los operadores jurídicos la subsunción de determinados elementos fácticos a su descripción típica. La práctica empresarial y laboral pretende constantemente escabullirse de la tinta sombría de muchos de los jurisconsultos, o bien para encontrar (o configurar retóricamente) su protección o para escapar de obligaciones dirigidas. En la práctica cotidiana los operadores jurídicos se encuentran con la realidad de varias empresas que si bien están dotadas cada una de personalidad jurídica propia (sociedad anónima, sociedad de responsabili-

52 Sentencia del Tribunal Constitucional, Rol núm. 534 de 2006.

53 Bernasconi, Andrés, "El carácter científico de la dogmática jurídica”, Revista de derecho de la Universidad Austral, vol. 20, núm. 1, 2007, pp. 9-37. También se recomienda revisar el artículo de Vergara Blanco, Alejandro, "Delimitar y distinguir: teoría del derecho, filosofía del derecho y doctrina jurídica”, Revista de derecho, Valparaíso, núm. 44, 2015, pp. 623-660. 
dad limitada, etcétera), en los hechos, funcionan todas como un solo grupo, ${ }^{54}$ o más bien como una sola unidad. ${ }^{55}$ En particular se hace presente esta situación respecto del ejercicio de la potestad de mando y dirección (usualmente con áreas de recursos humanos compartida).

El legislador, sin mayores preciosismos jurídicos, pero tampoco con la pulcritud mínima que fuese esperable de la entidad democrática encargada de la nomogenética, ha pretendido dar una solución a una dificultad que se presentaba en la técnica judicial de resolución de conflictos laborales, pero ha omitido valerse de uno de los elementos que pretéritamente permitían acceder a herramientas que guiasen óptimamente a una solución conforme con la juridicidad; nos referimos a las figuras jurídicas de simulación y subterfugio. Sin embargo, la apreciación legislativa difiere de lo expuesto y de manera optimista, con un ánimo de clausura, la autoridad laboral, esto es, la Dirección del Trabajo ha señalado que "la nueva normativa recepciona en toda su dimensión la doctrina judicial de la "unidad económica". ${ }^{56}$

Con esta reforma un trabajador, o varios, o los propios sindicatos, podrán solicitar que se declare la configuración jurídica de un sólo empleador con la finalidad de requerir el cumplimiento de determinadas obligaciones laborales, a pesar de existir en los hechos (y también para efectos jurídicos propios de otras ramas, como el derecho civil, derecho comercial, o el derecho tributario, por ejemplo) varias sociedades o personas jurídicas diferenciables. En principio, ya no sería necesario requerir la declaración fáctica con efectos jurídicos de funcionamiento de un determinado grupo como "unidad económica", sino que ahora el propio texto legal explícitamente otorgaría elementos normativos que permitan fundamentar dicha pretensión, al considerar a los sujetos como "único empleado" o "empleador común”. El nuevo precepto sirve de fundamento en la argumentación jurídica respectiva no sólo en un sentido retórico de la expresión, sino que sería la propia ley en su aplicación dinámica la que activaría una declaración de este tipo, sin que sea necesario, una vez más, como tantas otras veces, merodear por los deslindes difusos del principio de realidad, que pretendiese concebirlo no sólo como un principio sino que efectivamente como una norma decisoria directamente aplicable.

54 Rojas Miño, Irene y Aylwin Chiorrini, Andrés, "Los grupos de empresas...", cit., pp. 25 y ss.

55 López Fernández, Diego, “La empresa como unidad”, cit., pp. 57-78.

56 Dirección del Trabajo, Ord. 3406/054 de 3 de septiembre de 2014. 


\section{El artículo $507{ }^{57}$ actual del Código del Trabajo viene a reemplazar lo consa- grado previamente en el artículo $478^{58}$ del mismo cuerpo legal, que en su mo-}

57 Artículo 507. "Las acciones judiciales derivadas de la aplicación del inciso cuarto del artículo 3o. de este Código podrán ser ejercidas por las organizaciones sindicales o trabajadores de las respectivas empresas que consideren que sus derechos laborales o previsionales han sido afectados. Estas acciones podrán interponerse en cualquier momento, salvo durante el período de negociación colectiva a que se refiere el Capítulo I del Título II del Libro IV de este Código; si el procedimiento judicial iniciado sobrepasa la fecha de presentación del proyecto de contrato colectivo, los plazos y efectos del proceso de negociación deberán suspenderse mientras se resuelve, entendiéndose para todos los efectos legales prorrogada la vigencia del instrumento colectivo vigente hasta 30 días después de ejecutoriada la sentencia, día en que se reanudará la negociación en la forma que determine el tribunal, de acuerdo con lo dispuesto en la ley. Lasentencia definitiva que dé lugar total o parcialmente a las acciones entabladas deberá contener en su parte resolutiva:

1. El pronunciamiento e individualización de las empresas que son consideradas como un solo empleador para efectos laborales y previsionales, conforme a lo señalado en el inciso cuarto del artículo 3o. de este Código.

2. La indicación concreta de las medidas a que se encuentra obligado el empleador dirigidas a materializar su calidad de tal, así como aquellas destinadas al cumplimiento de todas las obligaciones laborales y previsionales y al pago de todas las prestaciones que correspondieren; bajo apercibimiento de multa de 50 a 100 unidades tributarias mensuales, la que podrá repetirse hasta obtener el debido cumplimiento de lo ordenado.

3. La determinación acerca de si la alteración de la individualidad del empleador se debe o no a la simulación de contratación de trabajadores a través de terceros, o bien a la utilización de cualquier subterfugio, ocultando, disfrazando o alterando su individualización o patrimonio, y si ello ha tenido como resultado eludir el cumplimiento de las obligaciones laborales y previsionales que establece la ley o la convención. Si así lo determina, deberá señalar de manera precisa las conductas que constituyen dicha simulación o subterfugio y los derechos laborales y previsionales que por esta vía se hubieren vulnerado, debiendo aplicar al infractor una multa de 20 a 300 unidades tributarias mensuales. En estos casos, será aplicable a las multas señaladas lo dispuesto en el inciso quinto del artículo 506 de este Código. Quedan comprendidos dentro del concepto de subterfugio referido en el párrafo anterior, cualquier alteración de mala fe realizada a través del establecimiento de razones sociales distintas, la creación de identidades legales, la división de la empresa, u otras que signifiquen para los trabajadores disminución o pérdida de derechos laborales individuales o colectivos, en especial entre los primeros las gratificaciones o las indemnizaciones por años de servicios y entre los segundos el derecho a sindicalización o a negociar colectivamente. La sentencia definitiva se aplicará respecto de todos los trabajadores de las empresas que son consideradas como un solo empleador para efectos laborales y previsionales. Las acciones a que se refieren los incisos precedentes podrán ejercerse mientras perdure la situación descrita en el inciso cuarto del artículo 3o. de este Código, sin perjuicio de lo dispuesto en el inciso segundo del presente artículo".

58 Artículo 478. "Se sancionará con una multa a beneficio fiscal de 5 a 100 unidades tributarias mensuales al empleador que simule la contratación de trabajadores a través de terceros, cuyo reclamo se regirá por lo dispuesto en el artícu- 
mento había pretendido también satisfacer los requerimientos de justicia para aquellos casos en que se pretendía evitar la aplicación de la ley laboral dejando a los trabajadores en posiciones desmejoradas, pero que igualmente fue vista como insuficiente ${ }^{59}$. La nueva normativa vigente regula en el precepto citado fundamentalmente los requisitos que ha de cumplir el juzgador en la dictación de la sentencia que ha de pronunciarse sobre la acción interpuesta en virtud de lo dispuesto en el artículo 3o. del Código del Trabajo, que a su vez autoriza accionar fundado en la pretensión de lograr la declaración de único empleador por existir una dirección laboral común entre dos o más empresas. Es en este contexto que se regula la posibilidad de sancionar conductas que puedan cons-

lo 474. Sin perjuicio de lo anterior, el empleador y los terceros deberán responder solidariamente por los derechos laborales y previsionales que correspondan al trabajador. El que utilice cualquier subterfugio, ocultando, disfrazando o alterando su individualización o patrimonio y que tenga como resultado eludir el cumplimiento de las obligaciones laborales y previsionales que establece la ley o la convención, será sancionado con una multa a beneficio fiscal de 10 a 150 unidades tributarias mensuales, aumentándose en media unidad tributaria mensual por cada trabajador afectado por la infracción, cuyo conocimiento corresponderá a los Juzgados de Letras del Trabajo, con sujeción a las normas establecidas en el Título I de este Libro. Quedan comprendidos dentro del concepto de subterfugio, a que se refiere el inciso anterior, cualquier alteración realizada a través del establecimiento de razones sociales distintas, la creación de identidades legales, la división de la empresa, u otras que signifiquen para los trabajadores disminución o pérdida de derechos laborales individuales o colectivos, en especial entre los primeros las gratificaciones o las indemnizaciones por años de servicios y entre los segundos el derecho a sindicalización o a negociar colectivamente. El empleador quedará obligado al pago de todas las prestaciones laborales que correspondieren a los trabajadores quienes podrán demandarlas, en juicio ordinario del trabajo, junto con la acción judicial que interpongan para hacer efectiva la responsabilidad a que se refiere el inciso segundo. El plazo de prescripción que extinga las acciones y derechos a que se refieren los incisos precedentes, será de cinco años contados desde que las obligaciones se hicieron exigibles".

59 “...la solución derivada del acuerdo transaccional obtenido en el Congreso Nacional el año 2001 en orden a postergar la regulación de la subcontratación y que se reflejó en parte en el nuevo texto del artículo 478 del CdT incorporado por la Ley núm. 19.759 no fue satisfactoria. En efecto, dicha norma, que fue concebida con el fin de otorgar un cierto resguardo a los trabajadores suministrados, sancionando la simulación de la contratación de trabajadores a través de terceros, así como los subterfugios destinados a ocultar, disfrazar o alterar la individualización o patrimonio de la empresa con vistas a afectar los derechos individuales y/ o colectivos de los trabajadores, no contribuyó a mejorar la situación laboral y previsional de los trabajadores subcontratados, debido a la dificultad que implicaba el establecimiento de este ilícito laboral y por la discusión generada acerca de si era o no necesario establecer una conducta dolosa del empleador para poder configurarlo y hacer efectivas las sanciones pecuniarias". Caamaño Rojo, Eduardo, "La ley de subcontratación y la tutela de los derechos fundamentales de los trabajadores de servicios transitorios", Revista Ius et Praxis, Talca, vol. 13, núm. 2, 2007, pp. 157-194. 
tituir subterfugio o simulación laboral, subordinadas ambas figuras a la declaración antedicha, y por tanto tipificadas como una sanción accesoria.

En este contexto, es preciso escudriñar sobre las consecuencias normativas que conlleva la consagración legislativa de los tipos de subterfugio y simulación laboral como tipos secundarios, desde la entrada en vigencia de la reforma a la que hemos hecho referencia, y, obviamente, qué podemos desprender de su nueva configuración textual dispuesta en el enunciado normativo respectivo. ¿A qué nos referimos con simulación y subterfugio?, ¿existe un elemento subjetivo del tipo en las figuras enunciadas?, ¿tienen aplicación autónoma?, ¿a quién se encomienda la aplicación de sanción por incurrir en dichas conductas? Éstas serán alguna de las temáticas que se pretenden exponer críticamente en las siguientes líneas, enunciando una aproximación hacia los deslindes de cada uno de estos cuestionamientos posibles por la consagración normativa señalada, los espacios de discusión que el legislador ha dejado abierto, y en ciertos casos, las posibles soluciones que pueden proponerse.

\section{SIMULACIÓN Y SUBTERFUGIO: ALGUNOS CONFLICTOS HERMENÉUTICOS POSIBLES}

El análisis de los conceptos de "subterfugio"60 y de "simulación"61 situados en sede laboral no ha estado exento de comentarios y análisis doctrinarios. Así,

60 Lanata señala al respecto que "se comprende dentro del concepto de subterfugio, cualquier alteración realizada a través del establecimiento de razones sociales distintas, la creación de identidades legales, la división de empresa, u otras que signifiquen para los trabajadores disminución, pérdida de derechos laborales individuales (especialmente gratificaciones o indemnizaciones por años de servicio) o colectivos (especialmente el derecho a sindicalización o negociar colectivamente)". Lanata Fuenzalida, Gabriela, Contrato individual de trabajo, 4a. ed., Santiago de Chile, Thomson Reuters, 2010, p. 202.

61 En relación a la relevancia de la simulación contractual en sede laboral se ha señalado por Irene Rojas que "En efecto, el problema se ha planteado con la simulación contractual en cuanto se celebra formalmente un contrato afín, generalmente un contrato de arrendamiento de servicios, en circunstancias que encubre un contrato de trabajo. En esta simulación una o ambas partes tienen un interés directo. El empleador pretende aminorar los costos laborales y disminuir su nivel de responsabilidad empresarial impuesta por las normas laborales. El trabajador, por su parte, pretende una calidad de trabajador independiente y, supuestamente, evitaría el descuento de las cotizaciones por concepto de seguridad social. No obstante, en muchos casos es discutible la existencia de este interés económico por parte del trabajador, toda vez que simultáneamente pierde la protección de los instrumentos de seguridad social. Así, en muchos casos es más sostenible la imposición por parte del empleador de este contrato simu- 
por ejemplo, Ugarte ha señalado en su oportunidad, con la normativa vigente previo a la reforma, que "la figura del artículo 478, inciso primero, del Código del Trabajo no es, en estricto rigor, un caso de simulación al modo de la doctrina civil, sino un caso de fraude a la ley laboral, sancionado con especial rigor después de la última reforma laboral"'62 refiriéndose a la Ley núm. 19.759, que el año 2011 modificó el artículo 478 del Código del Trabajo. Añade inmediatamente además que "es posible sostener que en materia laboral, la conducta que se busca sancionar no es el engaño a terceros, ni siquiera al propio trabajador involucrado, sino la elusión del vínculo laboral, y la aplicación de las normas imperativas del derecho del trabajo, mediante la concurrencia de un empleador formal (el tercero que celebró el contrato de trabajo) que se superpone y encubre al empleador real (a quien el trabajador presta sus servicios)". ${ }^{63}$

En otra publicación del profesor Ugarte, al abordar el análisis del uso abusivo de múltiples razones sociales para efectos laborales ha señalado que

...la multiplicidad de personas jurídicas que suscriben formalmente los contratos de trabajo, permiten lograr un resultado prohibido por la ley laboral: que se utilice como centro de imputación normativa, y lugar de ejercicio de derechos laborales, a quien no tiene la calidad de empleador para efectos de las normas laborales. Es en este caso que se puede hablar de uso fraudulento de la personalidad jurídica en el ámbito laboral.

El uso fraudulento en el ámbito laboral puede afectar tanto derechos individuales - por ejemplo, si la persona jurídica que firma los contratos es la menos solvente para responder de las gratificaciones o las indemnizaciones - o derechos colectivos — como por ejemplo, si la empresa se divide artificialmente haciendo imposible el ejercicio efectivo del derecho a negociar colectivamente-.$^{64}$

De manera expresa el profesor Ugarte ha señalado, como indicamos previamente, que "ni este proyecto ni el del gobierno de Piñera aceptaron el

lado, respecto del cual el trabajador solo podrá cuestionar su configuración jurídica una vez que termine la vigencia de la relación, con el problema añadido que será él quien deba probar la relación jurídica laboral". Rojas Miño, Irene, Derecho del trabajo. Derecho individual del trabajo, Santiago de Chile, Thomson Reuters, 2015, p. 31.

62 Ugarte Cataldo, José Luís, "La simulación laboral del artículo 478: un caso de fraude a la ley", Boletin oficial de la Dirección del Trabajo, núm. 173, 2003, p. 4.

63 Ibidem. p. 7.

64 Ugarte, José Luis, “La actual Corte Suprema...," cit., p. 2. 
punto básico del tema: que se trata de un fraude laboral que busca esconder detrás de la un pluralidad de personas jurídicas a un solo empleador". ${ }^{65}$ En esa misma lectura, la reforma carecería de un verdadero espíritu protector, como el que infunda a todo el derecho del trabajo, pues incluye nuevas exigencias que "no están en la legislación laboral vigente y, entonces, el cuadro es el de un perfecto retroceso: ahora con la nueva regulación propuesta los trabajadores que acrediten que todas estas razones sociales son un único empleador - porque tienen un sólo jefe, por ejemplo, que los manda a todos—, no habrán logrado superar el nuevo estándar que el Gobierno viene en exigirles". ${ }^{66}$

Bajo la aproximación dogmática de Ugarte las normas laborales analizadas pretenderían cautelar, en principio, la vigencia imperativa del propio derecho del trabajo, lo que permitiría en último término señalar que lo cautelado, al fin y al cabo, es la vigencia, imperatividad y eficacia del ordenamiento jurídico mismo. Señala Ugarte que "el fraude laboral puede ser conceptualizado como el incumplimiento de una norma o principio laboral imperativo, mediante una conducta externa formalmente acorde con otra norma legal que oculta o disimula la elusión de aquella". ${ }^{67}$ No se trata exclusivamente de una protección o cautela de la posición del trabajador en cuanto tal, pues en general, "en materia laboral, la conducta que se busca sancionar no es el engaño a terceros, ni siquiera al propio trabajador involucrado, sino la elusión del vínculo laboral, y la aplicación de las normas imperativas del derecho del trabajo, mediante la ocurrencia de un empleador formal (el tercero que celebró el contrato de trabajo) que se superpone y encubre al empleador real (a quien el trabajador presta sus servicios)" ${ }^{68}$ En dicha clave de lectura, ¿no resultaría un tanto paradójico que cualquier infracción laboral, aunque sea contractual, sería siempre una infracción al Derecho, pues eventualmente encontraría cobertura en el principio de autonomía de la voluntad y la doctrina civil, y entonces siempre una infracción laboral podría ser leída como un fraude "a la ley", o específicamente una infracción del orden jurídico laboral? En otras palabras, al no identificar al sujeto específico perjudicado o afectado jurídicamente por el despliegue de alguna conducta maliciosa, la sanción en sí misma, tal vez

\footnotetext{
65 Ugarte, José Luis, "Multirut. Mortalmente parecidos...", cit.

66 Idem.

67 Ugarte, José Luis, "El nuevo...," cit., p. 108.

68 Ibidem, p. 109.
} 
como quisiera el profesor Ugarte, sería siempre una sanción jurídica del Estado de derecho en tanto tal, con la mera (pero sistemáticamente relevante) pretensión de hacer efectivo en ese acto su propia vigencia, antes que cautelar posiciones subjetivas determinadas. En el mismo sentido lo ha comprendido el profesor Luis Lizama. ${ }^{99}$ Esta comprensión, como pasaremos a revisar, se ve superada, o a lo menos reconfigurada, por la propia técnica legislativa que ha utilizado el legislador en la dictación del nuevo artículo 507 del Código del Trabajo.

Quiroz Allende ha comprendido la figura de simulación en sede laboral de una manera similar a como el profesor Ugarte la ha estudiado, y ha señalado al respecto que

...[1]a simulación de contratación de trabajadores a través de terceros consiste, básicamente, en una pseudo-subcontratación y forma parte, por ende, de las figuras de cesión ilegal de trabajadores en general. Sin embargo, este ilícito presenta ciertas particularidades en relación con aquellas figuras, ya que no se trata sólo de una infracción a la ley laboral y, específicamente, a la regulación existente sobre externalización de los recursos humanos, sino que además, resulta posible enmarcarla dentro de los casos de fraude a la ley laboral, compartiendo al igual que el subterfugio. ${ }^{70}$

Pero, por otra parte, intentar utilizar la herramienta dogmática que permita una lectura del precepto citado conlleva otro inconveniente, pues resulta que en el análisis dogmático y doctrinario civil la figura del fraude a la ley no refiere a una imputación objetiva de responsabilidad por incumplimiento formal de determinada actuación, o desadecuación de las acciones desplegadas en relación con lo prescrito en la norma, sino que se ha requerido también que se presente un elemento subjetivo que permita atribuir la responsabilidad respectiva, o en términos generales, la sanción o consecuencia jurídica prescrita para dicha infracción. La comprobación de dicho elemento subjetivo en sede laboral, se ha señalado por la doctrina, resultaría ser una carga probatoria material sumamente gravosa para los trabajadores. En ese sentido, Gamonal

69 Lizama, Luis, Derecho del Trabajo, Santiago, Chile. Editorial LexisNexis, 2003, p. 50.

70 Quiroz Allende, Paulina Elizabeth, "Ley de subcontratación laboral. La simulación y el problema de la calificación jurídica de la inspección del trabajo", Revista de Derechos Fundamentales, núm. 12, 2014, pp. 233-248. 
señalaba que "en el fraude a la ley, en doctrina civil, se discute acerca de probar la intención, lo que representaría en materia laboral un obstáculo prácticamente insalvable. Por el contrario, el principio de primacía de la realidad es objetivo en su aplicación, respetando los dos elementos descritos, ya que se basa en la potestad de mando del empleador, dentro de la organización que organiza, dirige y administra, y donde se "inserta" el trabajador, lo que conlleva que la "realidad del contrato de trabajo" jamás se produce a "espaldas del empleador", ya que la ley le otorga poderes jerárquicos al interior de su empresa. Por ello la aplicación de este principio es objetiva y no requiere probar la intención del empleador". ${ }^{71}$

Sin embargo, hay que considerar que las figuras de simulación y subterfugio, tal como se han consagrado en materia laboral, no son creaciones doctrinarias dispuestas para la consecución de impugnación o anulabilidad de determinado acto jurídico, buscando la voluntad real de las partes para hacerla eficaz ante un tercero, sino que se ha dispuesto su consagración con la finalidad de consagrar una potestad sancionatoria del Estado (que antiguamente facultaba tanto a la administración como a la judicatura, pero actualmente la reserva de manera exclusiva a ésta última, como veremos en el apartado siguiente). Si a lo que nos enfrentamos es al ejercicio de la potestad punitiva del Estado (ius puniendi estatal), el ejercicio de éste ha de regirse por los principios que modelan el derecho sancionador del Estado, entre los cuales encontramos el principio de culpabilidad. ${ }^{72} \mathrm{El}$ ius puniendi estatal requerirá fundar su despliegue, a efectos sancionatorios, en una actuación intencionada del sujeto

71 Gamonal, Sergio, "Grupos de empresa y derecho laboral chileno...," cit., p. 124.

72 "La aplicación del principio de culpabilidad a las sanciones administrativas significa, en primer término, que éstas no pueden imponerse sino al infractor que ha actuado de forma dolosa o culposa. Existe consenso en nuestra doctrina y jurisprudencia respecto de la aplicación de este principio en materia de sanciones administrativas, aun cuando no se indica la fuente o fundamento de tal afirmación.

En efecto, para la doctrina penal es discutible que el principio de culpabilidad tenga un fundamento constitucional. Algunos han argumentado su existencia a partir del reconocimiento constitucional de la dignidad humana (artículo 1o. CPol.) o en el principio de la irretroactividad in peius (artículo 19, núm. 3 inciso 8o., CPol.). Sin embargo, la mayoría ha buscado su fuente en la prohibición de presumir de derecho la responsabilidad penal (artículo 19 núm. 3, inciso 7o., CPol.), en la medida que la culpabilidad es presupuesto de la responsabilidad penal, por lo tanto, presumir la culpabilidad de derecho significa también presumir dicha responsabilidad. En todo caso, se trata de un argumento no exento de críticas y que ha llevado a la doctrina penal a sostener que su afirmación a nivel constitucional constituye todavía una tarea incompleta. 
infraccional, pues no se encuentra democráticamente facultado para restringir dicha esfera de libertad por la mera constatación de un hecho externo. El principio de culpabilidad resulta también aplicable en esta sede.

En el presente caso hay dos estancos diversos de estudio: en primer lugar el análisis, la argumentación y la crítica sobre la posibilidad de poder restablecer que dos personas jurídicas, obviamente con razones sociales diversas, puedan ser para efectos laborales (por ahora) como una sola entidad, y así se le atribuya la posición subjetiva pasiva de la relación laboral, posibilitando su declaración de la calidad de empleador de los trabajadores respectivos. En ese ámbito es en donde se torna esencial la discusión sobre la determinación del sujeto empleador y trabajador, y la juridicidad de la aplicación de la teoría del "levantamiento del velo", ${ }^{73}$ o la afectación directa a la libertad de asociación, como derecho fundamental, entre otras cosas. En ese sentido se desarrolló en su momento la alegación sobre inconstitucionalidad del 183 ter, que se agregaba al Código del Trabajo mediante el artículo 3o. nuevo del Proyecto de Ley Boletín núm. 2943-13 sobre el trabajo en régimen de subcontratación, el funcionamiento de las empresas de servicios transitorios y el contrato de trabajo de servicios transitorios en que se consagraba un concepto legal de empresa con la omisión de la expresión "individualidad legal determinada". ${ }^{74}$

Ahora bien, no caben dudas que ya sea por su eventual reconocimiento constitucional o por la proyección de los principios del orden penal como derecho común del poder punitivo estatal, la culpabilidad constituye uno de los principios del derecho administrativo sancionador", Cordero Quinzacara, Eduardo, "Los principios que rigen la potestad sancionadora de la administración en el derecho chileno", Revista de Derecho de la Pontificia Universidad Católica de Valparaíso, Valparaíso, núm. 42, julio de 2014, pp. 420-421.

73 Ugarte Vial, Jorge, "Fundamentos y acciones para la aplicación del levantamiento del velo en Chile", Revista Chilena de Derecho, vol. 39, núm. 3, 2012, pp. 699-723.

74 "Dicha omisión permitiría a los entes administrativos desconocer su individualidad natural y cometer toda clase de abusos, lo que implicaba sumir a la empresa en un estado de incertidumbre jurídica, vulnerando la adecuada autonomía e individualidad de la empresa como cuerpo intermedio, violentándole su facultad de administración, al imponerle asociaciones no pactadas por sus miembros, e involucraba violaciones a los derechos fundamentales garantidos por la Constitución a dichas entidades. En suma, los requirentes plantearon que el nuevo artículo 183 ter vulneraba la debida autonomía que el Estado debe proporcionar a los grupos intermedios, según el artículo 10., inciso 3o., de la Constitución. Además, quebrantaba diversos artículos constitucionales, como la libertad de asociación, contemplada en el artículo 19, núm. 15; la libertad de contratación plasmada en el artículo 19, núm. 16; la libertad de empresa 
La anterior confusión es usual, pues incluso quienes, como Gamonal, estiman que las elaboraciones doctrinarias civiles no han de ser fácil y directamente transportables a sede laboral, olvidan a su vez, que además de dicha prevención, habrá que distinguir si el resultado de la aplicación de las figuras de simulación y subterfugio se ha dispuesto para efectos de i) la determinación de sujetos pasivos obligados al cumplimiento de obligaciones laborales y previsionales; o ii) si la simulación o subterfugio serán el fundamento de la aplicación de la potestad sancionatoria del Estado, sea la administración o el juez los entes empoderados para aquello, como ocurría en la legislación vigente previo a la Ley Multirut, o sea solamente el juez de la respectiva causa, como ocurre en este caso. Pareciese que el ámbito normativo que dispone el mecanismo idóneo de identificación del sujeto pasivo de la obligación laboral se encuentra en el artículo 3o., y la simulación y subterfugio son sólo figuras secundarias que legitiman la imposición de alguna sanción pecuniaria por el juzgador.

En otra vereda, el profesor Claudio Palavecino ha señalado, analizando el mismo precepto en cuestión (ex artículo 478 del Código del Trabajo), que “el bien jurídico protegido es el crédito laboral y el crédito de la seguridad social y el objeto material es la identidad del empleador como sujeto de imputación de tales créditos que la simulación pretende ocultar", ${ }^{75}$ y asimismo, que se trata de "un tipo de mera actividad puesto que no se exige una consecuencia más allá de la acción de simular. Es también un tipo de peligro abstracto puesto que no se requiere la comprobación un perjuicio real ni un peligro en tal sentido respecto de los trabajadores". ${ }^{76}$ Compartimos la apreciación del profesor Palavecino, y creemos que dicha consideración de fondo ha sido conservada aún después de la modificación legal implementada con la denominada "Ley Multirut".

tutelada en el artículo 19, núm. 21; el derecho de propiedad recogido en el artículo 19, núm. 24; y, por último, violaba el artículo 19, núm. 26, entrampando el libre ejercicio de los derechos mencionados, afectándolos en su esencia. Argumentaron, igualmente, que el actual artículo 478 del Código del Trabajo sancionaba ya la simulación y que, consecuentemente, las hipótesis que sustentaban el nuevo artículo 183 ter estaban debidamente cubiertas en la legislación laboral". Ribera Neumann, Teodoro, "La protección constitucional de la empresa...”, cit., p. 276.

75 Palavecino Cáceres, Claudio, "La simulación y el subterfugio laborales", Revista Chilena de Derecho del Trabajo y de la Seguridad Social, vol. 4. núm. 7, 2013, p. 14.

76 Palavecino Cáceres, Claudio, "La simulación y el subterfugio laborales...", cit., p. 16. 
Ahora bien, es preciso señalar que la segunda afirmación efectuada por el profesor Palavecino en relación a la simulación, para algunos podría parecer la tónica del legislador utilizada en la Ley Multirut, sin embargo el nuevo artículo 507, tanto respecto a la simulación como a la figura del subterfugio requiere como antecedente copulativo verificar previa aplicación de la respectiva sanción "si ello ha tenido como resultado eludir el cumplimiento de las obligaciones laborales y previsionales que establece la ley o la convención". Indirectamente requiere un resultado pernicioso para los afectados, lo que permite reafirmar que ya no cabe lugar a la interpretación de que estas figuras de simulación y subterfugio serían asimilables a un fraude a la ley.

En efecto, en doctrina se ha distinguido claramente entre las tres figuras; subterfugio, simulación y fraude a la ley, ${ }^{77}$ estableciendo elementos típicos, o a lo menos dogmáticos de identidad respecto de cada uno de ellos. Compartimos con Irureta en ese sentido que "en materia de fraude y simulación el ordenamiento laboral no constituye un 'recinto cerrado a cal y canto', ni menos autosuficiente" 78 y asumimos en todo caso que la tarea dogmática laboral está aún en deuda, proyectándose su delimitación.

Por otro lado, tampoco creemos que se trate de fraude a la ley, como sostuvieron entonces Ugarte e Irureta, ${ }^{79}$ sino que más bien, como sucede con las mayorías de las instituciones clásicas provenientes de otras áreas del derecho, ${ }^{80}$ se han insertado al discurso ius laboral con un espíritu sui generis, y por lo mismo es preciso adoptar como herramientas dogmáticas idóneas flexibles aquello que se ha expuesto respecto de cada una de las instituciones en sus áreas jurídicas especiales respectivas. Sin embargo, ¿la legislación laboral nos otorga elementos suficientes para cumplir dicha tarea y no vulgarizar

77 Martínez Cohen, Rafael, "El error, la simulación, el fraude a la ley y el abuso de un derecho en el derecho tributario chileno", Revista de derecho, Valparaíso, núm. 29, pp. 351-378. También véase Niño Tejeda, Eduardo, "La Simulación", Revista de Derecho de la Pontificia Universidad Católica de Valparaíso, núm. 14, 2007, pp. 71-96.

78 Irureta Uriarte, Pedro, "Simulación y apariencia en el ámbito laboral: la especial situación del sujeto contratante", Revista de derecho, Valparaíso, núm. 40, 2013, p. 218.

79 Ibidem, p. 217.

80 "Piénsese por ejemplo en el concepto de solidaridad en la subcontratación, limitada a un tiempo específico, y a determinadas obligaciones". Palavecino, Claudio, "La responsabilidad solidaria en la subcontratación laboral. Algunas consideraciones sobre su naturaleza y sus efectos", Revista Chilena de Derecho del Trabajo y de la Seguridad Social, vol. 1, núm. 1, primer semestre, 2010, pp. 17-27. 
en exceso las instituciones jurídicas tan ampliamente comentadas y analizadas por los doctrinarios más calificados del derecho?

José Luis Ugarte no otorga argumentos consistentes que permitan aseverar jurídicamente que estamos en presencia de un verdadero "fraude a la ley", y que permitan abandonar alternativas hermenéuticas como la expuesta por el profesor Palavecino. Podemos ser un tanto engreídos y sostener que el legislador no ha sido lo suficientemente docto en la elección de la terminología utilizada, más aún cuando sobre el concepto de simulación la doctrina y dogmática han desarrollado vastos pasajes de estudio, tanto en la cultura jurídica nacional como la comparada, sin embargo dicha consideración no nos puede permitir forzar irremediablemente el sentido del texto legal al punto de tergiversarlo y reemplazarlo por una institución a la que no se ha hecho referencia alguna, como se trata del caso de fraude a la ley.

La ubicación de ambas instituciones en el actual artículo 507 las sitúa como instituciones secundarias y dependientes. Aquello, bajo la lógica de que ya no resultaría de especial o particular relevancia, y de necesaria protección autónoma, la constatación objetiva de una situación de subterfugio o simulación ni menos aún los nuevos elementos subjetivos del tipo propio de cada una de estas dos instituciones resulte por sí misma objeto de especial cautela, sino que ésta se activaría sólo de manera subsecuente ante la constatación de un único empleador en los términos del artículo 30.

Parece que en este caso, tal como han acertado los autores en sus análisis, de manera explícita o implícita, no es propiamente una dimensión sancionatoria de la aplicación de la teoría del levantamiento del velo corporativo ${ }^{81}$ lo que ha venido a asentarse en la legislación laboral desde la entrada en vigencia del antiguo artículo 478 del Código del Trabajo. En ese sentido, y a pesar de los fundamentos políticos (no precisos desde un punto de vista jurídico) que se esgrimieron por el ejecutivo, la figura positivizada resulta independiente y autónoma de la aplicación y procedencia de la teoría de levantamiento del

81 "Disentimos de la tesis que postula un "fraude a la ley laboral", noción no aceptada por nuestra jurisprudencia y, de serlo, se corre el riesgo de que una interpretación civilista exija la prueba de intencionalidad del empleador. Lo mismo ocurre respecto de la doctrina del levantamiento de velo, aún no consolidada en nuestra jurisprudencia, a diferencia del señalado principio laboral, que es citado hace muchos años en nuestro medio judicial”. En nuestra opinión no es conveniente justificar las instituciones laborales por medio de las evoluciones posteriores del derecho civil. Gamonal, Sergio, "Grupos de empresa y derecho laboral chileno...”, cit., p. 126. 
velo $^{82}$, pues ni siquiera se ha abordado una determinada coherencia con las hipótesis de aplicación que han sido reconocidas en otras ramas del derecho, desde donde proviene esta institución, como lo son el Derecho Civil y Comercial. ${ }^{83}$ Señala al respecto Teodoro Ribera que "la Presidenta de la República basó sus argumentos en que el artículo 183 ter buscaba impedir que la subcontratación fuera utilizada como subterfugio para eludir obligaciones laborales y previsionales, principalmente en el caso de dos o más empresas que gozaban de identidad legal separada, pero que se caracterizaban por tener una misma estructura de mando. Se pretendía hacer primar, indicó, la realidad económica por sobre una estructura jurídica definida. Así, basado en la "doctrina del levantamiento del velo" y en el "principio de la primacía de la realidad”, el Gobierno alegó que el artículo en cuestión tenía por objeto evitar el fraude y proteger al trabajador, la parte más débil de la relación laboral". ${ }^{84} \mathrm{~A}$ su vez, dicho profesor comprendía en relación al levantamiento del velo que "lo que busca esta técnica es evitar la infracción a la ley perpetrada mediante el abuso de la cobertura formal que proporciona la persona jurídica, haciendo primar la realidad ante la apariencia". 85

Luego, una segunda cuestión, es la dinámica de la activación del ius puiniendi estatal ante la concurrencia de un tipo infraccional, consistente en la simulación o subterfugio laboral. Entonces, una vez superada la discusión anterior, o inclusive con prescindencia de ella, desde un punto de vista dogmático, es preciso avocarse al estudio directo de las figuras de simulación y subterfugio laboral como figuras punitivas. Ahora bien, en un plano meramente dogmá-

82 Procedimiento judicial "en virtud del cual se permite excepcionalmente al juez prescindir en un caso concreto de la personalidad jurídica y patrimonio separado de una sociedad, en términos tales que los derechos u obligaciones que se ha tratado de eludir mediante la comisión de un acto fraudulento se atribuyan directamente a quien ha cometido o permitido tal abuso, sea que se trate de un socio, de un administrador con poderes para controlar de hecho a la compañía o de una sociedad relacionada". Ugarte Vial, Jorge, "Fundamentos y acciones para la aplicación del levantamiento del velo en Chile...”, cit., p. 700.

83 "El abuso de la forma societaria y la consiguiente aplicación de la técnica judicial del levantamiento del velo tienen lugar ante la presencia de dos supuestos copulativos: primero, la identidad personal o patrimonial entre una sociedad y uno o más de sus socios, administradores o sociedades relacionadas; y segundo, la instrumentalización abusiva de tal sociedad para la consecución de un fraude a la ley o a los derechos de terceros". Ibidem, p. 701.

84 Ribera Neumann, Teodoro, "La Protección Constitucional de la Empresa:...", cit., p. 277.

85 Ibidem, p. 291. 
tico dicha distinción debiese ser autosuficiente y poder esclarecer en cierta medida su ámbito de aplicación normativa, sin embargo, al acercarnos a su constructo legislativo nacional encontramos inmediatamente que las figuras sancionatorias no son independientes y autónomas, sino que han pasado a consagrarse como posibilidades meramente secundarias y represivas.

Lo sancionable o reprimible por el Estado es la modalidad en que se ha llegado a cometer la infracción laboral que ha hecho necesaria la aplicación del artículo 3o. del Código del Trabajo. Esto es, del universo de formas en que pudieron haber actuado las respectivas empresas en su práctica cotidiana, y que llegaron a hacer necesaria y procedente la aplicación del artículo 3o. del Código del Trabajo, y por tanto, la declaración de único empleador por concurrir una dirección laboral común respecto de las diversas empresas (más los otros elementos que hemos enunciado previamente), el legislador ha considerado que se han de sancionar exclusivamente aquellas modalidades que permitan verificar simulación o subterfugio (actualmente sólo por el juez del trabajo, y sólo y exclusivamente a propósito de la resolución que acoge la acción de declaración de único empleador contenida en el artículo 3o.).

En el proceso indagatorio efectuado por el juez, y por la propia Inspección del Trabajo en el respectivo informe preliminar, se ha de verificar que, más allá de existir indicios que guíen a la corroboración de existencia de dirección laboral común, existe algún acto jurídico simulado (o disimulado) o se ha descubierto que las empresas en cuestión han incurrido en conductas constitutivas de subterfugio. Puede ocurrir que aquello no sea así, y que a pesar de aquello el juez termine acogiendo la demanda interpuesta, declarando la existencia de un único empleador. Por lo mismo resulta de especial preocupación que el respectivo magistrado que pretenda hacer ejercicio de la función punitiva del Estado tenga presente la distinción respectiva, y domine lo suficiente los tipos de simulación y subterfugio a fin de fundamentar consistentemente su sentencia. Por de pronto, creemos que si efectivamente nos encontramos ante una simulación ilícita o una conducta constitutiva de subterfugio no sería preciso argumentar sobre la inocuidad ius fundamental de la actividad desplegada por las empresas, pues éstas no gozarían de ninguna protección constitucional en dichos casos. En otras palabras; si se está ante un subterfugio o simulación ilícita no corresponde desarrollar una argumentación sobre la improcedencia de la supuesta aplicación de la teoría 
del levantamiento del velo corporativo, y de que la vulneración de derechos fundamentales supuestamente se produciría con ocasión de su instrumentalización como herramienta dogmática por parte del juez, pues el problema se encuentra previamente resuelto: allí donde existe una conducta ilícita, sea simulación ilícita o subterfugio, no existe cobertura ius fundamental, y ningún derecho fundamental del empleador resulta lesionado.

\section{HACIA UNA DETERMINACIÓN DE LOS CONCEPTOS DE SIMULACIÓN Y SUBTERFUGIO EN EL ACTUAL ARTíCULO 507 DEL CóDIGO DEL TRABAJO}

La ley laboral no ha otorgado una definición de subterfugio ni de simulación, por lo mismo hemos de recurrir a lo que la doctrina en otras sedes ha señalado al respecto. En ese sentido podemos señalar que estamos ante un negocio simulado cuando nos enfrentamos a aquel "que tiene una apariencia contraria a la realidad o porque no existe en absoluto, o porque es distinto de como aparece". 86

Desde una perspectiva eminentemente civilista, en donde la autonomía de la voluntad resulta un presupuesto formal de funcionamiento del ordenamiento jurídico es posible afirmar que

... [e]1 Derecho, substancialmente, es voluntad. Voluntad del que manda o concede; voluntad de los que convienen. Los actos de aquél constituyen el derecho general; los de éstos, el derecho particular. En el ámbito de éste último suele ocurrir el fenómeno de la divergencia entre la voluntad interior u real y la voluntad exteriorizada o aparente. A veces esta distorsión es deliberada y se habla entonces de simulación. El trato que se dé a esta última dependerá de la solución que tenga la cuestión previa sobre cual voluntad debe prevalecer: la subjetiva o interna o la objetiva o externa. ${ }^{87}$

Dicha posición formal es criticable desde un punto de vista filosófico, y hasta doctrinario, sin embargo, asumiendo su utilidad dogmática podría presentar cierta utilidad en la comprensión del fenómeno jurídico. No obstante,

86 Ferrara, Francisco, "La simulación en los Negocios Jurídicos", Revista de Derecho Privado, Madrid, 1953, p.43.

87 Niño Tejeda, Eduardo, “La Simulación”, cit., p. 71. 
los efectos laborales de dichas consideraciones voluntarias, ¿`serían fácilmente transportables a la dogmática laboral? Pareciese que precisamente el derecho laboral, en tanto estatuto positivo de la contratación dirigida no se satisface con una consideración de tal tipo, aunque necesariamente debe recurrir a dichas consideraciones para el develamiento de su propia naturaleza. En específico porque pareciese que la voluntad real o aparente no pueden otorgar una respuesta suficiente ante un fenómeno que puede estar considerado explícitamente en uno u otro fenómeno, menos aun cuando en la doctrina laboral se ha erigido fundamentalmente sobre una consideración prevaleciente de la externalidad, antes que la intencionalidad subjetiva de los actores sujetos a su ordenamiento normativo.

Por su parte, en el caso del subterfugio el profesor Palavecino ha pretendido su diferenciación con la figura de la simulación a través de un análisis del tipo, en conformidad al texto normativo vigente previo a la dictación de la Ley Multirut, y al efecto ha señalado que habría que analizar a las acciones o conductas que se encuentran tipificadas (en aquél entonces "ocultar, disfrazar o alterar"), ${ }^{88}$ ahora bien, como pasaremos a analizar, ni siquiera ese intento nos permite elucidar cuál es el contenido normativo de la figura contemplada en la ley.

Planet se ha pronunciado también sobre los conflictos que plantea la aproximación dogmática a la figura consagrada en el artículo 507 del Código del Trabajo (previo a la entrada de vigencia de la Ley Multirut) y al tipo de subterfugio, señalando que

...si bien la mayoría de la doctrina sostiene que el subterfugio corresponde a un ilícito de resultado, bastando la mera existencia del resultado perjudicial en los derechos laborales, la jurisprudencia emanada de los Tribunales Superiores de Justicia, ha tendido a exigir dolo para su configuración, por tratarse de una simulación o fraude a la ley... exigir intencionalidad al subterfugio implicaría que todo subterfugio para dificultar la negociación colectiva correspondería necesariamente a una práctica desleal de aquellas contenidas en el artículo 387 letra c) del mismo cuerpo legal. ${ }^{89}$

88 Palavecino Cáceres, Claudio, "La Simulación y el Subterfugio Laborales", cit., p. 19.

89 Planet, Lucía, "El grupo de empresas y la negociación colectiva", Gaceta jurídica, Santiago de Chile, núm. 391, 2012, p.17. 
Dicha definición vuelve sobre un punto que hemos abordado previamente, y que evidencia que la mayoría de la doctrina laboralista está por concebir al subterfugio y simulación laboral desprovistos de un elemento subjetivo, en donde el juzgador, en el ejercicio del ius puniendi, prescinda del principio de culpabilidad para aplicar la correspondiente sanción.

La simulación por definición puede ser lícita o ilícita, ${ }^{90}$ siendo sólo este último caso el que a petición de parte puede ser impugnado como acto en cuanto perjudicaría a un tercero, sin embargo en la nueva figura contemplada en la ley no existe por el legislador una elucidación contundente. Sin perjuicio de lo anterior, debemos acoger como un gran avance en el diseño normativo la consagración de un requisito de mala fe respecto del subterfugio, y de un resultado lesivo tanto para la simulación como para el subterfugio, lo que viene a aclarar en gran medida la discusión expuesta en párrafos previos sobre el elemento subjetivo del tipo sancionatorio.

Por otra parte, con la nueva configuración normativa el legislador ha pretendido no entregar absolutamente al desarrollo doctrinario y elucubración teórica y jurisprudencial el contenido del concepto de subterfugio, y si bien no describe precisamente a qué refiere dicha expresión legal, sí otorga a vía ejemplar la enunciación de ciertas conductas que calificarían como tal, señalando que nos encontramos ante el subterfugio cuando constatamos cualquier alteración de mala fe realizada a través:

a. del establecimiento de razones sociales distintas,

b. la creación de identidades legales,

c. la división de la empresa,

d. u otras que signifiquen para los trabajadores disminución o pérdida de derechos laborales individuales o colectivos, en especial entre los primeros las gratificaciones o las indemnizaciones por años de servicios y entre los segundos el derecho a sindicalización o a negociar colectivamente.

La primera de las hipótesis consagrada por el legislador aparenta ser, en principio, de suma amplitud, pues refiere a cualquier alteración aunque, contrario a lo que podría pensarse en una primera lectura, las supuestas alteraciones en las palabras siguientes, no referirán propiamente a la conducta eventual-

90 Irureta Uriarte, Pedro, "Simulación ...”, cit., p. 215. 
mente lesiva, sino más bien al resultado lesivo de la conducta, esto es, el legislador ha sido cauteloso utilizando una técnica legislativa en la cual el resultado amplio es lo que termina por otorgar una mayor protección de los derechos de los trabajadores. Acto seguido, el legislador nutre de un tipo subjetivo a la norma potestativa sancionadora, e indica que no se trata de cualquier conducta desplegada por el infractor, sino sólo aquellas que hayan sido cometidas "de mala fe"; he aquí un elemento subjetivo del tipo del que deberá hacerse cargo el magistrado que haya dado lugar a la sanción.

Extrañamente, y como ya el lector podrá haberse percatado hasta este punto, el legislador ha establecido sólo al final de la enunciación antes transcrita, la conducta, o acción que activa la aplicación de la sanción por incurrir en subterfugio. En efecto, se reserva para el final de la oración el develamiento de que la conducta constitutiva de infracción que ha de ser sujeta a evaluación o directamente analizada en sus diversos aspectos para determinar si la sanción procede o no. Señala entonces que la acción es el "establecimiento de razones sociales distintas". Por establecimiento hemos de comprender, conforme al espíritu de la ley, que se refiere a "creación" de razones sociales distintas, sin embargo, dicha vía hermenéutica implicaría que no quedan comprendidas en ésta conducta tipificada las situaciones en que una misma persona, natural o jurídica, adquiriese una sociedad ya existente (fusión), e incurra en una conducta de subterfugio. Además, el tipo en cuestión sería absolutamente ineficaz por reiterar lo que vendría inmediatamente después. Por lo mismo, la expresión establecimiento de razones sociales diversas puede referirse a una creación originaria en la cual, desde los inicios, el agente infraccional ha determinado, de mala fe, que dicha constitución societaria diversificada le permitirá vulnerar o perjudicar a futuro los derechos de los trabajadores que serán contratados por ésta.

Habiendo recorrido el camino inverso, por la técnica legislativa utilizada, encontramos que sintéticamente incurre en subterfugio quién establece raz̧ones sociales distintas (divide sociedades, o las crea), de mala fe, produciendo cualquier alteración que signifiquen para los trabajadores disminución o pérdida de derechos laborales individuales o colectivos.

Nuevamente encontramos un escollo terminológico amplio e indeterminado, pues el tipo descrito parece diferenciar, en esta versión, entre la expresión "cualquier alteración" y el resultado lesivo de una conducta determinada, 
cuál sería la disminución o pérdida de derechos laborales. En otros términos, la alteración refiere a algo distinto necesariamente al efecto lesivo de la conducta, pero a su vez, difiere también de lo que es propiamente la conducta, esto es, el establecimiento de razones sociales distintas. En ese sentido, puede referirse a la distribución del trabajo, la repartición de funciones de trabajadores que se encontraban contratados con una de las sociedades, alteraciones en cuanto a los beneficios que percibirían cada uno de los trabajadores contratados, entre otros.

Cada una de las tres hipótesis principales expuestas requiere además la presencia del resultado lesivo contemplado en la última parte de dicho inciso. Esto es: el respectivo establecimiento de razones sociales distintas a la mala fe y que producen cualquier alteración; la creación de identidades legales; la división de una sociedad; todas estas conductas han de contar con el resultado tipificado en la ley para la procedencia de declaración de subterfugio, lo que significa para los trabajadores disminución o pérdida de derechos laborales individuales o colectivos.

A su vez, tal como hemos señalado a propósito de la conducta del establecimiento de razones sociales distintas, las otras dos hipótesis también han de contar con los mismos elementos restantes, siendo aplicables las mismas críticas previamente expuestas.

Sin embargo, el legislador en la técnica nomogenética utilizada al cierre del enunciado transcrito comete una infracción al principio de juridicidad evidente. Configura una hipótesis normativa sancionatoria de carácter amplio e indeterminado, a través de la expresión “u otras". Más bien, no sólo configura una atribución sancionatoria amplia, sino que ha dejado indeterminada la hipótesis que autorizaría al Estado juez sancionar y desplegar el ius puniendi estatal ante quién supuestamente ha incurrido en una situación de subterfugio. $\mathrm{O}$, desde otra lectura, ha devuelto completamente el estatus de indeterminable al concepto de subterfugio, pues si bien en un principio pretendió determinar las hipótesis normativas señalando cuáles serían las acciones que darían aplicación al tipo, al consagrar en la fórmula textual normativa la expresión "u otras", ha dejado vaciado de contenido el propio concepto de subterfugio. Pues ni siquiera se refiere a si se trata de "otras similares", que pudiésemos ampliamente, y aún de manera un tanto vaga, relacionar con modificaciones societarias, y el ejercicio de la coordinación social. Pero, ¿puede legítimamente abrirse a la absoluta indeterminación de la hipótesis sancionatoria que autori- 
za al ejercicio del ius puniendi estatal? Nos parece que no sería procedente, en primer lugar, porque con dicha técnica legislativa, y de manera contradictoria, al enunciar e intentar determinar lo que el subterfugio pretende significar, se logra absolutamente lo contrario, volviendo a la evidente imposibilidad de determinación; y en segundo lugar, porque está vedado a cualquier órgano del Estado actuar vulnerando el principio de juridicidad, conforme al cual se consagra "la sujeción integral a Derecho de los órganos del Estado tanto en su ser como en su obrar". ${ }^{91}$ En este caso, el presupuesto, o hipótesis normativa que autoriza o faculta al Estado juez para el ejercicio legítimo del ius puniendi estatal ha quedado desprovisto de contenido e indeterminado, por lo que ha perdido fundamento cualquier ejercicio potestativo que se oriente en ese sentido.

Por otro lado, debemos tener presente que en materia sancionatoria, y en virtud del principio de legalidad, la interpretación de cualquiera de las hipótesis que determinen la procedencia de la infracción ha de ser interpretada restrictivamente, en virtud del principio de culpabilidad. Y además han de respetar el principio de tipicidad. ${ }^{92}$

Respecto de la simulación el legislador no ha optado por la misma vía, y no ha siquiera enunciado cuáles serían las hipótesis de aplicación normativa de la respectiva sanción judicial. Con ello afirmamos que en este caso ni siquiera hay un problema de técnica legislativa relacionado con la imposibilidad de determinación textual y normativa, sino que derechamente en este caso existe ausencia de la misma.

No obstante, tal como se puede desprender del texto legal, y de lo que ha señalado la Dirección del Trabajo en su Ord.: 3406/054 de 3 de septiembre de 2014 debemos recordar en este punto, que aunque puede ocurrir el caso de que nos enfrentemos a una situación en que proceda la aplicación de la nueva configuración del artículo 3o. del Código del Trabajo, y encontremos una dirección laboral común bajo los indicios allí expuestos, y que además dicha circunstancia resulte declarada en una sentencia judicial, aquello implicaría la concurrencia de las figuras de simulación o subterfugio que pretendan perjudicar a los trabajadores.

91 Soto Kloss, Eduardo, Derecho administrativo: bases fundamentales. El principio de juridicidad, Santiago de Chile, Editorial Jurídica de Chile, 1996, t. II, p. 24.

92 Cordero Quinzacara, Eduardo, "Los principios...", cit., p. 415. 
La participación de la autoridad administrativa en la subsunción jurídica de las figuras de simulación y subterfugio es (o debiese ser) nula, pues ni la ley le ha otorgado dicha facultad ni la propia autoridad laboral administrativa se ha atribuido ninguna competencia al respecto ni menos podría hacerlo en virtud del respeto del principio de juridicidad. En otras palabras, la Dirección del Trabajo no puede pronunciarse sobre la verificación de un subterfugio o simulación laboral. ${ }^{93}$

\section{ALCANCES DE LA NUEVA FORMA \\ DE REGULACIÓN DEL ARTÍCULO 507 EN TORNO \\ A LAS FIGURAS DE SUBTERFUGIO Y SIMULACIÓN ${ }^{94}$}

Tal como hemos señalado previamente, la regulación normativa actual de las figuras de subterfugio y simulación, más allá de lo que oportunamente se ha analizado en doctrina, permiten afirmar a lo menos lo siguiente:

a) No se trata de figuras autónomas contempladas en el Código del Trabajo. ${ }^{95}$

b) La sanción por las conductas allí tipificadas sólo es sancionable a través de la aplicación de una multa ${ }^{96}$ por el órgano jurisdiccional (Estado juez)

93 Aquello resulta evidente de mayor manera tras la lectura de la circular núm. 61 de 10 de septiembre de 2014 que "imparte instrucciones sobre modalidades y procedimientos de actuación inspectiva respecto a multiplicidad de razones sociales", pues ninguno de sus acápites realiza mención o instrucción alguna a la propia autoridad laboral en lo referido a la calificación jurídica de subterfugio o simulación.

94 Un estudio relevante que pretende abordar la lectura de las figuras propuestas desde un enfoque dogmático cercano al derecho administrativo sancionador en coherencia con el garantismo penal, y en conexión con la noción unificada del ius puniendi estatal, es posible de encontrar en la memoria de grado: Durán Carvajal, Camilo Salvador, "Análisis de las figuras contempladas en el art. 507 del Código del Trabajo. La simulación y el subterfugio”, Memoria para optar al grado de Licenciado en Ciencias Jurídicas y Sociales, Universidad de Chile, 2014.

95 “....actualmente no procede ejercerse la acción ni declararse el subterfugio independientemente del empleador común, porque tal como concluye la Corte de Apelaciones de Concepción "la figura del subterfugio independiente de la declaración del acogimiento de la acción del artículo 3o., inciso 4o., del Código del Trabajo no existe". Conclusión que resulta ajustada a derecho luego de las modificaciones introducidas por la Ley W 20.760 al Código del Trabajo". Fernández Toledo, Raúl, "Empleador único (unidad económica)...”, cit., p. 201.

96 "Si se examina el artículo 507 del Código del Trabajo el único efecto que tiene la declaración de subterfugio es la aplicación de una multa a las empresas que han incurrido en dicho 
más no por la autoridad administrativa, lo cual resulta coherente con el principio de juridicidad o legalidad, en cuanto acertadamente nuestros tribunales superiores de justicia ${ }^{97}$ han estado contestes en que la calificación jurídica de ciertas relaciones jurídicas como una de naturaleza laboral (lo que sería presupuesto de la aplicación de la sanción de simulación y subterfugio) es de competencia exclusiva de tribunales. ${ }^{98}$

c) Se excluyen figuras de simulación y subterfugio que no sean derivadas de la constatación de la declaración de una dirección laboral común (por ejemplo, queda fuera del tipo la cesión ilegal de trabajadores ${ }^{99}$ entre empresas absolutamente diversas, o entre aparentes subcontratistas).

d) No existe una acción autónoma que otorgue legitimación activa ni a los trabajadores individualmente considerados, ni a los sindicatos, ni a la Dirección del Trabajo, para denunciar ante el órgano jurisdiccional la constatación de situaciones de subterfugio y simulación laboral.

ilícito laboral, ninguna otra consecuencia jurídica. Las principales consecuencias jurídicas el legislador las reservó para la declaración de empleador común”. Ibidem, p. 202.

97 Una posición crítica de esta opción jurisprudencial: "El principal problema en cuanto al resguardo y protección de los derechos de los trabajadores, se produce a nivel de los tribunales superiores de justicia, a través del uso que las empresas han hecho del recurso de protección para dejar sin efecto las decisiones administrativas, en vez de la reclamación judicial. Por esta vía, la Corte Suprema ha ido invalidando el proceder de la Dirección del Trabajo transformando a la Ley 20.123 en letra muerta". Quiroz Allende, Paulina Elizabeth, "Ley de subcontratación laboral...", cit., p. 240.

98 "En ninguna de las atribuciones que el Código del Trabajo y la Ley Orgánica de la Dirección del Trabajo le entregan a esta autoridad, está aquella que dice relación con la facultad de interpretar contratos, calificar jurídicamente los hechos constatados ni menos reconocer la existencia de relaciones laborales en casos que no son claros, precisos y determinados. Las normas referidas entregan a la Dirección del Trabajo atribuciones relacionadas con fiscalizar la aplicación de las leyes del trabajo — cuando se esté ante relaciones de trabajo reguladas por el Código del Trabajo- y eventualmente interpretar la legislación laboral, pero no atribuciones jurisdiccionales, materia de exclusiva competencia de los tribunales de justicia". Gajardo Harboe, María Cristina, "Las Sentencias de la Ley de Subcontratación: una lección laboral del principio de legalidad de la administración”, Sentencias Destacadas 2008, Instituto Libertad y Desarrollo, pp. 251-252.

99 En su momento Irene Rojas llamaba la atención sobre esta dificultad, y la eventual progresión que se avizoraba en la materia, especialmente en situaciones en que la descentralización productiva, en casos en que la contratación de suministro de trabajo y subcontratación no era más que la figura formal de una vulneración de derechos laborales, con la sanción a la infracción de cesión ilegal con la dictación de la ley 19.250 de noviembre de 1993. En Rojas Miño, Irene, "La externalización laboral y la cesión ilegal de trabajadores...”, cit., pp. 186 y ss. 
e) Puede concederse la acción declarativa de dirección laboral común sin que sea procedente la aplicación de ninguna sanción por subterfugio ni simulación laboral, puesto que la acción de simulación y subterfugio resultan "prejudiciales" de la acción de unidad económica. ${ }^{100}$

f) No existe en el derecho laboral una acción autónoma de simulación o subterfugio laboral (que podría resultar de utilidad ante los casos de contratación a honorarios que sea fraudulenta o la cesión ilegal de trabajadores entre empresas distintas).

De lo anteriormente expuesto podemos deducir que si bien la reforma legal implementada ha pretendido otorgar una herramienta legítima de acción a disposición de los diversos operadores jurídicos laborales a fin de perseguir la declaración de empleador común, precisamente por la dirección común de empresas, simultáneamente se ha restado independencia a las figuras de subterfugio y simulación laboral, dejando desprovistos de herramientas legales a los trabajadores en aquellos casos en que su pretensión no sea la principalmente la de obtener la declaración de único empleador, sino que cuando buscasen la sanción directa de comisión de simulación o subterfugio que pudiese causar algún perjuicio en dichos actores.

En ese sentido, acertadamente ha señalado Mario Chacana que

....al reducir ambos ilícitos laborales a elementos agravantes de una sentencia que se pronuncia sobre otras materias, el legislador tácitamente excluyó la posibilidad de que los trabajadores puedan accionar en contra de un empleador fundándose exclusivamente en la existencia de la simulación y subterfugio, ya que la concurrencia de dichos elementos debe necesariamente tener por antecedente una acción de "Multirut". ${ }^{101}$

100 "La acción de subterfugio es prejudicial a la acción de empleador único, debido a que para que sea resuelta es necesario que se emita un pronunciamiento favorable sobre la acción de empleador único. También es accesoria, al ser subordinada y dependiente a la acción de declaración de empleador único. Lo que trae como consecuencia práctica que debe ejercerse conjuntamente con la acción de empleador común y que si se rechaza esta acción se rechaza también la acción de subterfugio por esa sola circunstancia. Por el contrario, si se acoge la acción de declaración de empleador común debe examinarse si las empresas demandadas incurrieron en subterfugio, de haberse ejercido esta acción por la parte trabajadora", Fernández Toledo, Raúl, “Empleador único (unidad económica)...”, cit., p. 202.

101 Chacana, Mario, “¿Fin a la simulación y subterfugio como ilícito laboral?”, El Mercurio 
Al condicionar la sanción de la simulación y subterfugio a la declaración de único empleador por concurrir una dirección laboral común respecto de varias empresas, implícitamente se ha excluido una figura sancionatoria que pudiese resultar relevante; la simulación absoluta. La sujeción de la sanción de la simulación del acto jurídico desplegado por el supuesto empleador supone siempre la existencia de al menos dos actos jurídicos, o dos objetos de intención distinguibles (una voluntad interna y una manifestación externa de la voluntad), por lo que nos enfrentamos a lo que se ha denominado "simulación relativa”, en la que se ha permitido distinguir entre el acto simulado, y el acto disimulado. Sin embargo, la simulación absoluta, esto es, aquél contrato de trabajo exteriorizado y aparente que no esconde ningún acto detrás de sí, queda excluido de la sanción. En ese sentido Toyama ha señalado que

...hay casos donde se suscriben sendos CT [contratos de trabajo] y hay cotizaciones a la seguridad social, pero, en los hechos, no existe un trabajo efectivo pues los acuerdos solamente se suscribieron para acceder a las prestaciones de la seguridad social: "Se produce una apariencia externa de que un determinado contrato de trabajo existe, e incluso se dan determinadas consecuencias jurídicas propias de un contrato real y válido (cotizaciones a la Seguridad Social e, incluso en ocasiones, el reconocimiento de prestaciones)". La simulación, entonces, es una discrepancia entre la voluntad declarada y la voluntad interna, producida por un acuerdo previo de ambas partes. Si no existe este acuerdo, estamos ante "un mero disfraz que, por carencia de causa, determina la inexistencia del contrato". 102

Respecto de la simulación relativa señala el mismo autor que "en materia laboral, usualmente se denomina a esta institución como 'desnaturalización' del contrato y la consecuencia, en el marco del principio de primacía de la realidad, es que existe un CT a plazo indeterminado". ${ }^{103}$

Por otra parte, tampoco se ha establecido, como tal vez lo hubiese deseado el profesor Ugarte, una hipótesis de fraude a la ley laboral susceptible de

Legal, Chile, 2015, disponible en: http:/ / wmw.elmercurio.com/Legal/Noticias/Opinion/2014/12/15/ Fin-de-la-simulacion-y-subterfugio-como-ilicito-laboral.aspx, consultado el 29 de noviembre de 2016.

102 Toyama, J., "Validez y eficacia del contrato de trabajo", Derecho PUCP, núm. 68, 2012, p. 462, disponible en: http:// revistas.pucp.edu.pe/index.php/derechopucp/article/view/2842/2771, consultado el 10 de enero de 2017.

103 Ibidem, p. 463. 
sanción bajo algún tipo contemplado en la ley laboral, pues por el contrario, si bien previamente tampoco se hacía mención explícita a esta institución o figura jurídica, menos aún cabe su invocación cuando no existe siquiera alguna institución autónoma que por vía interpretativa, como pretende Ugarte, pueda ser guiada hasta lograr su configuración. Si ya bajo lo expuesto resulta meramente secundario y derivativa la aplicación de las figuras de subterfugio y simulación laboral, menos aún ahora por vía interpretativa podríamos arribar a su encuentro.

Cabe mencionar que las figuras descritas no distinguen las diversas situaciones que se pueden presentar no sólo para los casos de simulación ilícita, o de subterfugio que tenga por objeto perjudicar a los trabajadores, sino para aquellos casos en que materialmente algún operador al interior de los grupos de empresas pueda excederse en el ejercicio de supuestos o aparentes poderes de dirección o mando (tal vez es más adecuado señalar que impropiamente se extralimitan o actúan fuera de ellos), y el problema jurídico que se plantea ante dicha efectividad material. ${ }^{104}$

Si bien es conocido que las figuras de simulación y subterfugio jamás fueron ampliamente aplicadas por nuestros tribunales laborales ni menos se hizo un uso pulcro y erudito de cada una de dichas instituciones, con la actual legislación parece que resultará aún más recóndita su aplicación y procedencia. Puede pensarse que la exigencia de cierto tipo subjetivo, (en todo caso propio de cada una de dichas instituciones) pareciese excesiva ante los requerimientos que pudiésemos realizar a la argumentación jurídica interna del juez laboral, sin embargo, el legislador ha dispuesto una composición mucho más perniciosa; se ha derivado a una estancia secundaria la aplicación de las figuras precitadas, siempre condicionada a la procedencia de un presupuesto previo cual es el de la declaración de la dirección laboral común.

Tal vez es lo que ha parecido más razonable al legislador, pues ya constatado que la sola declaración de dirección laboral común, y todas e inimagina-

104 "El problema se plantea para los juristas en cuanto este elemento no es verificable de modo similar que una sociedad, por lo que requiere de una revisión de una diversidad de elementos, que verifiquen dicha dirección unitaria”. Rojas Mino, Irene y Aylwin Chiorrini, Andrés, "Los Grupos de Empresas en el sistema jurídico de relaciones laborales en Chile", Revista Ius et Praxis, Talca, vol. 11, núm. 1, 2005, pp. 93-131. 
bles consecuencias que esto puede acarrear ${ }^{105}$ ya es suficiente sanción para el empleador, reservándose de manera calificada para casos de una gravedad y relevancia de mayor tono la procedencia de sanciones conforme al ejercicio del ius puniendi estatal.

\section{LA SANCIÓN CONTEMPLADA EN LA LEY COMO EJERCICIO DEL IUS PUNIENDI ESTATAL A TRAVÉS DEL ESTADO JUEZ}

El Estado juez se encuentra llamado a resolver en la sentencia definitiva que dé lugar total o parcialmente a las acciones entabladas en conformidad a lo dispuesto en el artículo 3o. del Código del Trabajo, si es que "la alteración de la individualidad del empleador se debe o no a la simulación de contratación de trabajadores a través de terceros, o bien a la utilización de cualquier subterfugio, ocultando, disfrazando o alterando su individualización o patrimonio, y si ello ha tenido como resultado eludir el cumplimiento de las obligaciones laborales y previsionales que establece la ley o la convención". Luego, la facultad sancionatoria entregada al órgano jurisdiccional competente se activa sólo una vez que ha sido ya declarada una alteración de la individualidad del empleador. Por consiguiente, resulta evidente la dependencia condicionada de la verificación sancionatoria de una situación de simulación o subterfugio.

Añádase a lo anterior que al subordinar las figuras de simulación y subterfugio laborales a la interposición de la acción que se desprende del artículo 3o. del Código del Trabajo se les ha quitado plena independencia y autonomía, como hemos señalado precedentemente, y por lo mismo las situaciones en que los trabajadores pudiesen constatar situación de simulación laboral, pero que no concurran simultáneamente con alteraciones artificiales de la individualidad del empleador, éstos quedarían absolutamente desprovistos de protección.

Pero, ahora bien, continuando con la lectura del precepto legal en comento nos percatamos que éste señala que el juez "deberá señalar de manera precisa las conductas que constituyen dicha simulación o subterfugio y los derechos laborales y previsionales que por esta vía se hubieren vulnerado, debiendo aplicar al infractor una multa de 20 a 300 unidades tributarias mensuales.

105 En lo que refiere a Reglamento interno, sistemas de remuneraciones, extensión de planes de beneficios, etcétera. 
En estos casos, será aplicable a las multas señaladas lo dispuesto en el inciso quinto del artículo 506 de este Código". ${ }^{106}$ Por tanto, de la remisión normativa consagrada por el legislador podemos deducir que la respectiva multa podría ser desde 20 UTM hasta 900 UTM, dependiendo de la realidad concreta de la empresa en cuestión.

Se trata de un caso ejemplar en que nos enfrentamos al Estado juez, fuera del ámbito propiamente penal, ejerciendo el denominado ius puniendi estatal con la finalidad de reprimir directamente conductas contrarias a derecho, desplegadas por agentes particulares. Constatamos además que se trata de una facultad discrecional del juez, quién se enfrenta a un rango abierto para la determinación exacta de la multa con que se sancionará la infracción en cuestión, cuestión que sin duda, en virtud de la garantía de respeto al debido proceso, y el imperativo de racionalidad de la sentencia, ha de ser lo suficientemente justificada y argumentada en el razonamiento judicial que despliegue el sentenciador.

De la norma en análisis podemos desprender además que no se trata de un tipo sancionatorio de mero peligro, sino que a efectos de proceder la aplicación de la sentencia en cuestión debe el magistrado señalar específicamente:

a) La conducta que constituye simulación o subterfugio.

b) Los derechos laborales y previsionales que por esta vía se hubiesen vulnerado.

A su vez, tal como hemos expuesto en los puntos anteriores, cada uno de estos dos elementos que han de ser considerados elementos esenciales en el desarrollo argumentativo del juez que pretende aplicar la sanción establecida en la ley, está compuesto a su vez de otros elementos que son igualmente indeterminados, lo que sin duda pone en riesgo el eventual control e la potestad sancionatoria del Estado, que al menos en este caso, ha de respetar las preceptivas ius fundamentales en materia procesal.

106 El inciso quinto del artículo 506 señala: "En el caso de las multas especiales que establece este Código, su rango se podrá duplicar y triplicar, según corresponda, si se dan las condiciones establecidas en los incisos tercero y cuarto de este artículo, respectivamente y de acuerdo a la normativa aplicable por la Dirección del Trabajo". A su vez, el artículo 506 incisos tercero y cuarto señalan, respectivamente que: "Tratándose de medianas empresas, la sanción ascenderá de 2 a 40 unidades tributarias mensuales". "Tratándose de grandes empresas, la sanción ascenderá de 3 a 60 unidades tributarias mensuales”. 
El problema ineludible, en todo caso, es que el juzgador además debe hacerse cargo de las elucubraciones doctrinarias en torno a las figuras de simulación y subterfugio, para efectos de otorgar racionalidad y dotar de juridicidad y legitimidad al ejercicio del ius puniendi estatal. La hipótesis sancionatoria es un concepto jurídico indeterminado, cuyo análisis no puede ser obviado por el juzgador si no quiere evacuar una sentencia carente de sostén, y en último término, de legitimidad.

\section{A MODO DE CONCLUSIÓN}

El legislador a través de la emisión de la Ley Multirut ha pretendido otorgar mayor certeza a los operadores jurídicos, y en particular a los trabajadores, en cuanto a la determinación de los sujetos pasivos obligados al cumplimiento de las obligaciones laborales y previsionales. Su intención ha sido disminuir los grados de difuminación de los obligados a dar pago a los respectivos créditos laborales, procurando impedir que la responsabilidad de estos se difumine a través del ejercicio ilegítimo de la libertad de empresa, a través de acciones que puedan eventualmente constituir incluso simulación o subterfugio.

Sin embargo, el propio legislador ha diferenciado las últimas dos figuras precitadas de la declaración de único empleador. Por un lado, parte del nuevo precepto contenido en el artículo 507 vela por la garantía de los créditos laborales permitiendo la declaración de único empleador, independientemente de las intenciones subjetivas o maliciosa voluntad con que haya operado el respectivo empleador. Por lo mismo, ha diferenciado la posibilidad de dicha declaración judicial, con la medida sancionatoria que el Estado juez ha de imponer al agente que haya operado en tal sentido, y que además haya incurrido en una conducta constitutiva de simulación o subterfugio.

No bastando lo anterior, luego de condicionar la potestad sancionatoria del órgano jurisdiccional ante la verificación de un único empleador, ha decidido otorgar elementos de tipo subjetivo a ambas figuras, pero a su vez ha incurrido en ciertas falencias, como la indeterminación de los presupuestos fácticos que harían procedente la aplicación de la respectiva multa.

Ante la realidad planteada, y habiendo el legitimado activo de la acción contenida en el artículo 3o. del Código del Trabajo obtenido la declaración de 
único empleador, es evidente que no se gastarán mayores recursos procesales en la sola persecución sancionatoria de los agentes que se estime hayan incurrido en alguna de las conductas contempladas en el artículo 507 número 3.

A su vez, al condicionar la aplicación de las instituciones señaladas al resultado de accionar conforme al artículo 3o., se deja desprovisto de acción a los trabajadores, sindicatos o terceros interesados (incluyendo la propia autoridad administrativa laboral), de perseguir por una vía autónoma e independiente una sanción por conductas de simulación no subsumibles al artículo 3 o. (cesión ilegal de trabajadores, el caso de los empaquetadores, ${ }^{107}$ trabajadores contratados a honorarios, etcétera).

Si bien la norma representa un avance en cuanto formaliza y permite judicializar legítimamente una pretensión que se guía tras la certeza de las relaciones laborales, podría pensarse que una consideración más amplia, incluso como la

107 "La simulación constituye una conducta infraccional en nuestra legislación laboral y se enmarca en el concepto de 'fraude laboral'. Esta figura está referida a la existencia de un empleador aparente u ostensible que en la realidad no lo es, es decir, se trata de un sujeto que formalmente se presenta como empleador contratante de un trabajador, no obstante que en los hechos el que ejerce el vínculo de subordinación o dependencia y que recibe y se beneficia con el producto de la labor realizada por aquél, resulta ser otro sujeto que no figura formalmente como empleador o en los instrumentos que documentan la relación laboral . El encubrimiento laboral es aquella situación en que existiendo relación laboral, el empleador intenta disfrazar la figura, dándole otra naturaleza jurídica, y por ende, haciendo inexistente el contrato de trabajo. El fraude laboral se configura en base a lo siguiente: a) Los empaquetadores al momento de ser seleccionados deben firmar un contrato de mandato, en el cual se señala que el empaquetador es quien 'manda' a la empresa intermediaria para que 'administre' sus turnos y realice las gestiones que tengan por fin obtener 'autorizaciones' para que éstos realicen sus labores 'independientes' al interior del supermercado. b) Además de esto, los aludidos, deben firmar una declaración jurada por medio de la cual se establece que los servicios son prestados de forma 'independiente', bajo su propia cuenta y riesgo, y a cambio del cual recibirán una propina voluntaria de parte de los clientes que solicitaren esos servicios. Acto seguido, se deja constancia de que no se tiene ningún vínculo laboral ni contractual con el supermercado ni con la empresa intermediaria. De lo anteriormente expuesto, podemos concluir que el empleador directo, la empresa que gestiona la administración de los turnos, por medio de la figura del mandato, intenta eludir su calidad de empleador directo para con los empaquetadores de supermercados, desconociendo la relación laboral existente, como también el régimen de subcontratación establecido entre la empresas de retail y las empresas contratistas que suministran trabajadores a cambio de la exclusividad del uso de las dependencias del local de supermercado". Passalacqua Vergara, Bruno y Ramírez Lazcano, Fernanda, "Situación de los empaquetadores de supermercado en Chile ¿constituye una relación laboral?”, Revista de Filosofía y Ciencias Jurídicas, año 1, núm. 1, diciembre 2012, pp. 24-29. 
que ya estaba vigente en el antiguo artículo 478 del Código del Trabajo, podría otorgar mayor protección a los trabajadores. Pero aún es corto el tiempo que ha estado en vigencia la ley como para hacer un diagnóstico acabado. Sin duda para otro estudio e investigación quedará pospuesta una investigación acabada del estado jurisprudencial actual en aplicación de la norma en comento.

\section{BiBLIOGRAFÍA}

ACKerman, Mario E., "Contrato de servicios y contrato de trabajo. La protección de la persona en las fronteras del derecho del trabajo", Revista Latinoamericana de Derecho, año IV, núm. 7-8, enero-diciembre de 2007.

Argueta R., Alejandro, El disfraz de la relación de trabajo en Guatemala, Central General de Trabajadores de Guatemala, Guatemala, 2008.

BARRETto GHiOne, Hugo, "La determinación de la relación de trabajo en la recomendación 198 y el fin del discurso único de la subordinación jurídica”, Revista Direito UNIFACS, núm. 129, 2011.

BERNASCONI, Andrés, "El carácter científico de la dogmática jurídica”, Revista de Derecho de la Universidad Austral, vol. 20, núm. 1, 2007.

CAAMAÑo Rojo, Eduardo, "El empleo en las fronteras del derecho del trabajo. El trabajo autónomo económicamente dependiente", Revista Laboral Chilena, núm. 132, diciembre de 2004, parte I.

CAAMAÑo Rojo, Eduardo, "El empleo en las fronteras del derecho del trabajo. El trabajo autónomo económicamente dependiente", Revista Laboral Chilena, núm. 133, enero de 2015, parte II.

CAAMAÑo Rojo, Eduardo, "Análisis crítico sobre la aplicación de la doctrina de los actos propios en materia laboral", Revista de Derecho, Valparaíso, núm. 32, 2009.

CAAMAÑo Rojo, Eduardo, "La ley de subcontratación y la tutela de los derechos fundamentales de los trabajadores de servicios transitorios", Revista Ius et Praxis, Talca, vol. 13, núm. 2, 2007.

CAVALlOTTI, Valentina, La locación de servicios como frande laboral, Universidad Siglo 21, Argentina, 2015 disponible en: bttps:/ / repositorio.uesiglo21.edu.ar/bitstream/ handle/ ues21/12870/CAVALLOTT1\%20Valentina.pdf?sequence $=1$.

CHACANA, Mario, “¿Fin a la simulación y subterfugio como ilícito laboral?”, El Mercurio Legal, Chile, 2015, disponible en: http://wnm.elmercurio.com/ 
Legal/Noticias/Opinion/2014/12/15/Fin-de-la-simulacion-y-subterfugio-comoilicito-laboral.aspx.

CORDERO QUinZACARA, Eduardo, "Los principios que rigen la potestad sancionadora de la Administración en el derecho chileno", Revista de Derecho de la Pontificia Universidad Católica de Valparaíso, Valparaíso , núm. 42, julio de 2014.

De Buen Unna, Carlos, "Los contratos colectivos de trabajo de protección patronal en México", Análisis político, México, Fundación Friedrich Ebert, 2011.

Durán CARvajal, Camilo Salvador, "Análisis de las figuras contempladas en el artículo 507 del Código del Trabajo. La simulación y el subterfugio", Memoria para optar al grado de Licenciado en Ciencias Jurídicas y Sociales, Universidad de Chile, 2014.

FERNÁNDEZ TOLEDO, Raúl, "Empleador único (unidad económica): requisitos de configuración, alcance de la exigencia dirección laboral común y procedencia de la acción de subterfugio. Comentario a la sentencia de Multirutl de la Corte de Apelaciones de Concepción, Rol Reforma Laboral núm. 76-2015". Revista Chilena de Derecho del Trabajo y de la Seguridad Social, vol. 6, núm. 11, 2015.

Ferrara, Francisco, "La simulación en los Negocios Jurídicos", Revista de Derecho Privado, Madrid, 1953.

Gajardo Harboe, María Cristina, "Las Sentencias de la Ley de Subcontratación: una lección laboral del principio de legalidad de la administración”, Sentencias Destacadas 2008, Instituto Libertad y Desarrollo, 2008.

GAMONAL, Sergio, "Grupos de empresa y derecho laboral chileno. Tensiones y problemas", en Rojas MiÑO, Irene y Aylwin Chiorrini, Andrés, Los grupos de empresas en el Derecho Chileno del Trabajo, LexisNexis, Chile. 2006.

GAMONAL, Sergio, Ciudadania en la empresa o los derechos fundamentales inespecificos, FCU, Montevideo, Uruguay, 2004.

Gamonal, Sergio, Fundamentos de derecho laboral, Santiago de Chile, Legal Publishing Chile, Thomson Reuters, 2014.

GINER, Salvador, El futuro del capitalismo, Península, Argentina, 2010.

Goldín, Adrián, "El fraude laboral y los contratos afines", La Ley, año LXXV, núm. 181, Argentina, 2011. 
IRURETA URIARTE, Pedro, "Simulación y apariencia en el ámbito laboral: la especial situación del sujeto contratante", Revista de Derecho, Valparaíso, núm. 40, 2013.

LANATA FuenZAlida, Gabriela, Contrato individual de trabajo, 4a. ed., Santiago de Chile, Thomson Reuters, 2010.

LASTRA LASTRA, José Manuel, "La buena fe en el trabajo; ¿un principio que se difumina?", Letras jurídicas: Revista de los Investigadores del Instituto de Investigaciones Jurídicas U. V., núm. 8, 2003.

LASTRA LASTRA, José Manuel, "Paradojas de la autonomía de la voluntad en las relaciones de trabajo", Revista de Derecho Privado, nueva serie, nueva época, año II, núm. 5, mayo-agosto, 2003.

Lizama, Luis, Derecho del trabajo, Santiago de Chile, LexisNexis, 2003.

LÓPEZ FERNÁNDEZ, Diego, La empresa como unidad económica, 2a. ed., Thomson Reuters, 2015.

MARTínez CoHEN, Rafael, "El error, la simulación, el fraude a la ley y el abuso de un derecho en el derecho tributario chileno", Revista de Derecho, Valparaíso, núm. 29, 2007.

MARTÍNEZ GARRIDO, Luis Ramón, "Contratas, cesión ilegal de trabajadores y cooperativas de trabajo asociado", Revista del Ministerio de Trabajo y Asuntos Sociales, núm. 38, 2002.

MATEO, José Antonio et al., "Precarización y fraude laboral en la industria pesquera marplatense. El caso de las cooperativas de fileteado de pescado. Estado actual de la situación y evolución histórica de la rama, 1989-2010”, El estado de la clase trabajadora en la Provincia de Buenos Aires, La Plata, Ministerio de Trabajo de la Provincia de Buenos Aires, CEIL-PIETTE (Conicet), 2011.

MuÑOZ, A., "Aplicación de la primacía de la realidad sobre la formalidad en los contratos de trabajo", Pensamiento Americano, Barranquilla-Medellín, vol. 5, núm. 8, enero-junio 2012.

NAVA, Yuneska y HeRnÁNDEZ, Carmen Añez, "Subcontratación: relación laboral encubierta", Telos. Revista de Estudios Interdisciplinarios de Ciencias Sociales, septiembre-diciembre de 2012.

Niño TejedA, Eduardo, "La Simulación”, Revista de Derecho de la Pontificia Universidad Católica de Valparaíso, núm. 14, 2007. 
Organización Internacional Del Trabajo (OIT), Panorama laboral normativo. En materia de libertad sindical y negociación colectiva en américa latina y caribe, Brasil, OIT, 2016.

Palavecino CÁCERES, Claudio, "De la empresa como pura facticidad a la relación de trabajo sin contrato", Revista Chilena de Derecho del Trabajo y de la Seguridad Social, vol. 2, núm. 4, 2011.

Palavecino CÁCERes, Claudio, "El concepto de empresa y su problemática”, Revista Laboral Chilena, julio, 2008.

PALAVECINO CÁCERES, Claudio, "El tipo subjetivo en la simulación y subterfugio en perjuicio de los trabajadores", El Mercurio Legal, Chile, 2013, disponible en: http://wnw.elmercurio.com/Legal/Noticias/Opinion/2013/04/01/ El-tipo-subjetivo-en-la-simulacion-y-subterfugio-en-perjuicio-de-los-trabajadores.aspx.

PALAVECINO CÁCERES, Claudio, "La responsabilidad solidaria en la subcontratación laboral. Algunas consideraciones sobre su naturaleza y sus efectos", Revista Chilena de Derecho del Trabajo y de la Seguridad Social, vol. 1, no. 1, primer semestre, 2010.

PalaVecino CÁCERES, Claudio, "La Simulación y el Subterfugio Laborales", Revista Chilena de Derecho del Trabajo y de la Seguridad Social, vol. 4, núm. 7, 2013.

PALOMO VÉLEZ, Rodrigo I., "Los grupos de empresas en el Derecho Chileno del Trabajo", Ius et Praxis, vol. 12, núm. 2, 2006.

Passalacqua Vergara, Bruno y Ramírez Lazcano, Fernanda, "Situación de los empaquetadores de supermercado en Chile ¿constituye una relación laboral?", Revista de Filosofía y Ciencias Jurídicas, año 1, núm. 1, diciembre 2012.

Plá Rodríguez, Américo, Los principios del derecho del trabajo, 3a. ed., Buenos Aires, De Palma, 1998.

PlAnET, Lucía, "El grupo de empresas y la negociación colectiva", Gaceta jurídica, número 391, Santiago de Chile, 2012.

Quiroz AlLENDE, Paulina Elizabeth, "Ley de subcontratación laboral. La simulación y el problema de la calificación jurídica de la inspección del trabajo", Revista de Derechos Fundamentales, núm. 12, 2014.

Ribera Neumann, Teodoro, "La protección constitucional de la empresa: la individualidad determinada y la teoría del levantamiento del velo", Sen- 
tencias Destacadas 2006, Ediciones Libertad y Desarrollo, Santiago de Chile, 2007.

ROJAS MiÑO, Irene, "La externalización laboral y la cesión ilegal de trabajadores en el sistema jurídico chileno", Revista Ius et Praxis, vol. 16, núm. 1, 2010.

RojAs MiÑo, Irene, Derecho del trabajo. Derecho individual del trabajo, Thomson Reuters, 2015.

RojAs MinO, Irene y AYLWIN CHIORRINI, Andrés, "Los grupos de empresas en el sistema jurídico de relaciones laborales en Chile", Revista Ius et Praxis, Talca, vol. 11, núm. 1, 2005.

RojAs Mino, Irene y AYLWIN CHIORRINI, Andrés, Los grupos de empresas en el Derecho Chileno del Trabajo, LexisNexis, Chile. 2006.

Romero Milano, Antonio, "Relaciones Laborales Encubiertas en Venezuela", Compendium: Revista de Investigación Cientifica, núm. 20, 2008.

Ruiz Medrano, Salvador Francisco y Cisneros Silva, Guadalupe, "El outsourcing desde la perspectiva jurídica, laboral y administrativa de México y el mundo y su problemática actual", Ponencia presentada en XV Congreso Internacional de Investigación en Ciencias Administrativas, Veracruz, 2011, disponible en: http://acacia.org.mx/busqueda/pdf/01_03_Outsourcing. $p d f$.

Servat Pereira de Sousa, Roberto Juan, "Causas de desnaturalización de los contratos de trabajo sujetos a modalidad en la legislación peruana", Revista Peruana de Derecho de la Empresa, Perú, año XIX, núm. 58, enero de 2005.

Sото KLOSS, Eduardo, Derecho administrativo: bases fundamentales. El principio de juridicidad, Santiago de Chile, Editorial Jurídica de Chile, 1996, t. II.

TAPIA, Francisco, "El concepto de empresa y los derechos sindicales en el derecho chileno del trabajo", Estudios en homenaje al profesor William Thayer A., Chile, Sociedad Chilena de Derecho del Trabajo y de la Seguridad Social, 1998.

TOYAma, J., "Validez y eficacia del contrato de trabajo", Derecho PUCP, núm. 68, 2012, disponible en: http:/ / revistas.pucp.edu.pe/index.php/ derechopucp/article/view/2842/2771.

UGARTE VIAL, Jorge, "Fundamentos y acciones para la aplicación del levantamiento del velo en Chile”, Revista Chilena de Derecho, vol. 39, núm. 3, 2012. 
UGARTE, José Luis, "Sobre relaciones laborales triangulares: la subcontratación y el suministro de trabajadores", Revista Ius et Praxis, Talca, vol. 12, núm. 1, 2006, disponible en: <http://www.scielo.cl/scielo.php?script=sci_ arttexteopid $=$ S0718-00122006000100002 $\sigma / n g=e s \& \mathrm{nrm}=i$ iso $>$. [Consultado el 06 de diciembre de 2016].

UgARTE, José Luis, El nuevo derecho del trabajo, Santiago de Chile, Universitaria, 2004.

UGARTE, José Luis, "La actual Corte Suprema y su particular concepto de empresa para efectos de la negociación colectiva", La Semana Jurídica, núm. 382, noviembre de 2008.

UGARTE, José Luis, "La simulación laboral del artículo 478: un caso de fraude a la ley”, Boletín oficial de la Dirección del Trabajo, núm. 173, 2003.

UGARTE, José Luis, "La tutela de derechos fundamentales y el derecho del trabajo: de erizo a zorro", Revista de Derecho, Universidad Austral de Chile, Valdivia, vol. XX, núm. 2, diciembre 2007.

UGARTE, José Luis, "Ley de Multirut: de vuelta a los gloriosos 90", El mostrador, Chile, 2014, disponible en: http://mwm.elmostrador.cl/noticias/opinion/2014/06/23/ley-de-multirut-de-vuelta-a-los-gloriosos-90/.

UGarTe, José Luis, "Multirut. Mortalmente parecidos", Diario electrónico "El Mostrador", Chile, 2014, disponible en: http:/ / www.elmostrador.cl/ noticias/opinion/2014/04/24/ multirut-mortalmente-parecidos/.

Vergara Blanco, Alejandro, "Delimitar y distinguir: teoría del derecho, filosofía del derecho y doctrina jurídica", Revista de derecho, Valparaíso, núm. 44, 2015.

Vergara Del Río, Mónica, "El concepto laboral de empresa y los créditos laborales”, Revista Laboral Chilena, año 13, núm. 12, 2003. Tु 